Technology Development

Division

Technology Development

Division

Technology Development

Division

Technology Development Division

Technology Development

Division

Technology Development

Division

Technology Development

Division

Technology Development

Division

Technology Development

Division

Technology Development

Divion

Technology Development

Division

Technology Development

Division

Technology Development

Drvision

Technology Development

Druision

Technology Development

Division

Technology Development

Division

Technology Development

\title{
Potential Sources of Experimental Validation for Burnup Credit
}

Division

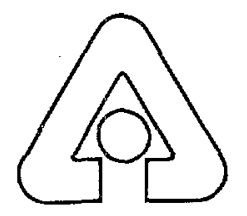

Argonne National Laboratory, Argonne, Illinois 60439

operated by The University of Chicago

for the United States Department of Energy under Contract W-31-109-Eng-38

Technology Development

Dhision

Technology Development

Division

Technology Developmert

ovision

Techmology Development

Division 
Argonne National Laboratory, with facilities in the states of Illinois and Idaho, is owned by the United States government, and operated by The University of Chicago under the provisions of a contract with the Department of Energy.

\section{DISCLAIMER}

This report was prepared as an account of work sponsored by an agency of the United States Government. Neither the United States Government nor any agency thereof, nor The University of Chicago, nor any of their employees or officers, makes any warranty, express or implied, or assumes any legal liability or responsibility for the accuracy, completeness, or usefulness of any information, apparatus, product, or process disclosed, or represents that its use would not infringe privately owned rights. Reference herein to any specific commercial product, process, or service by trade name, trademark, manufacturer, or otherwise, does not necessarily constitute or imply its endorsement, recommendation, or favoring by the United States Government or any agency thereof. The views and opinions of document authors expressed herein do not necessarily state or reflect those of the United States Government or any agency thereof, Argonne National Laboratory, or The University of Chicago.

Available electronically at http://www.doe.gov/bridge

Available for a processing fee to U.S. Department of Energy and its contractors, in paper, from:

U.S. Department of Energy

Office of Scientific and Technical Information

P.O. Box 62

Oak Ridge, TN 37831-0062

phone: (865) 576-8401

fax: (865) 576-5728

email: reports@adonis.osti.gov 


\section{DISCLAIMER}

Portions of this document may be illegible in electronic image products. Images are produced from the best available original document. 


\section{POTENTIAL SOURCES OF EXPERIMENTAL VALIDATION FOR BURNUP CREDIT}

by

Phillip Finck, Temitope Taiwo Argonne National Laboratory Technology Development Division

Jim Gulliford

AEA Technology

January 2000 
THIS PAGE INTENTIONALLY LEFT BLANK 


\section{TABLE OF CONTENTS}

Page

1. INTRODUCTION 1

2. SUMMARY OF EXPERIMENTS REVIEWED $\ldots \ldots \ldots \ldots \ldots \ldots \ldots$

3. FRENCH POST IRRADIATION EXAMINATION (PIE) DATA . . . . . . . 3

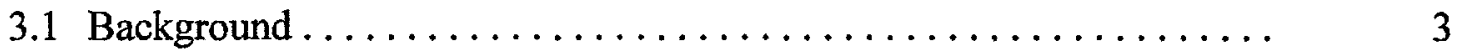

3.2 Rationale for the French Program $\ldots \ldots \ldots \ldots \ldots \ldots \ldots \ldots$

3.3 Chemical Analysis Programs $\ldots \ldots \ldots \ldots \ldots \ldots \ldots \ldots \ldots \ldots$

3.3.1 UO2 Programs $\ldots \ldots \ldots \ldots \ldots \ldots \ldots \ldots \ldots \ldots \ldots \ldots \ldots$

3.3.2 MOX Programs $\ldots \ldots \ldots \ldots \ldots \ldots \ldots \ldots \ldots \ldots \ldots \ldots \ldots$

3.3.3 BWR Fuel Programs $\ldots \ldots \ldots \ldots \ldots \ldots \ldots \ldots \ldots \ldots \ldots$

3.3.4 Other Fuel Analysis Programs . . . . . . . . . . . . . . 6

3.4 Code and Data Validation $\ldots \ldots \ldots \ldots \ldots \ldots \ldots \ldots \ldots \ldots \ldots \ldots \ldots$

3.5 Published Information $\ldots \ldots \ldots \ldots \ldots \ldots \ldots \ldots \ldots \ldots \ldots$

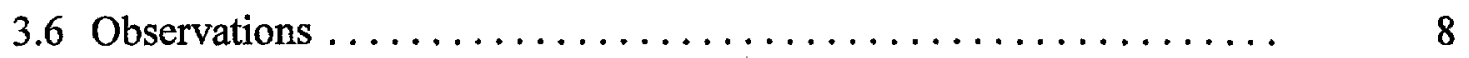

4. FRENCH VALDUC EXPERIMENT $\ldots \ldots \ldots \ldots \ldots \ldots \ldots \ldots \ldots \ldots$

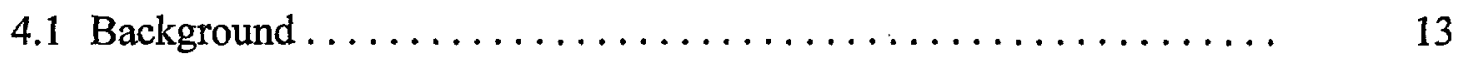

4.2 Fission Product Experimental Program $\ldots \ldots \ldots \ldots \ldots \ldots \ldots \ldots$

4.2.1 Physical Experiments $\ldots \ldots \ldots \ldots \ldots \ldots \ldots \ldots \ldots \ldots \ldots$

4.2.2 Dissolution Experiments $\ldots \ldots \ldots \ldots \ldots \ldots \ldots \ldots \ldots \ldots \ldots$

4.2 .3 Global Experiments $\ldots \ldots \ldots \ldots \ldots \ldots \ldots \ldots \ldots \ldots \ldots \ldots \ldots \ldots \ldots$

4.3 Published Information $\ldots \ldots \ldots \ldots \ldots \ldots \ldots \ldots \ldots \ldots \ldots \ldots \ldots$

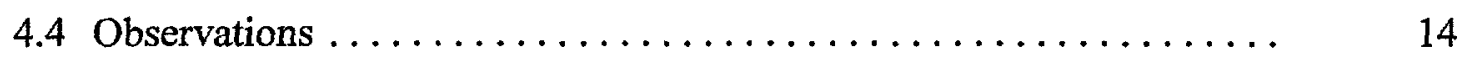

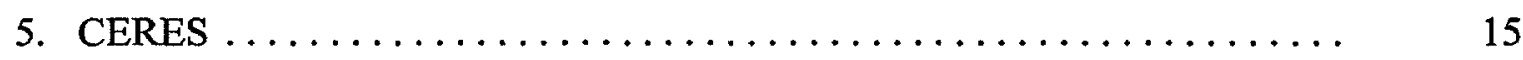

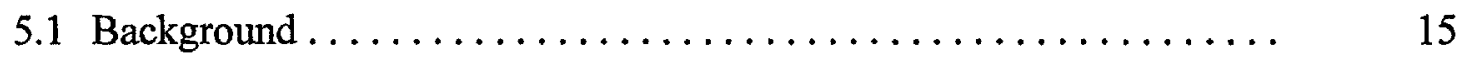

5.2 Summary of Technical Program $\ldots \ldots \ldots \ldots \ldots \ldots \ldots \ldots \ldots \ldots$

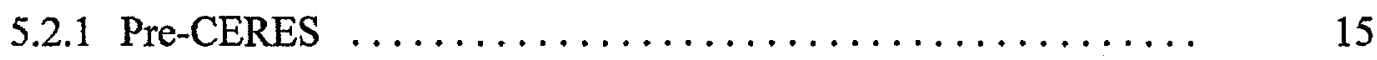

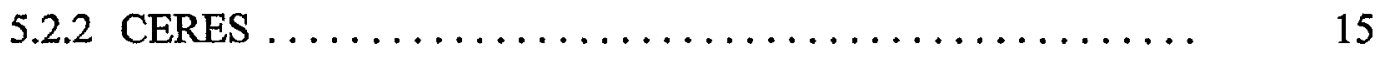

5.3 Published Information $\ldots \ldots \ldots \ldots \ldots \ldots \ldots \ldots \ldots \ldots \ldots \ldots$

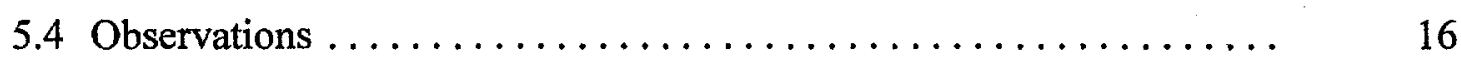

6. JAERI BURNUP CREDIT PROGRAM $\ldots \ldots \ldots \ldots \ldots \ldots \ldots \ldots \ldots$ 


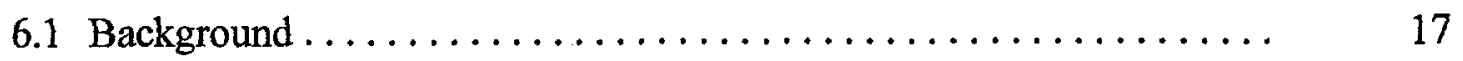

6.2 Technical Program $\ldots \ldots \ldots \ldots \ldots \ldots \ldots \ldots \ldots \ldots \ldots . . \ldots \ldots$

6.2 .1 Spent Fuel Reactivity ....................... 17

6.2.2 Worth of Individual Fission Products . .............. 17

6.3 Published Information $\ldots \ldots \ldots \ldots \ldots \ldots \ldots \ldots \ldots \ldots \ldots \ldots$

6.4 Observations $\ldots \ldots \ldots \ldots \ldots \ldots \ldots \ldots \ldots \ldots \ldots \ldots \ldots \ldots, \quad 18$

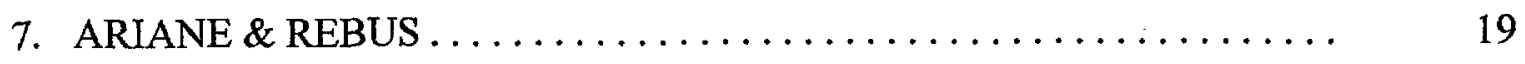

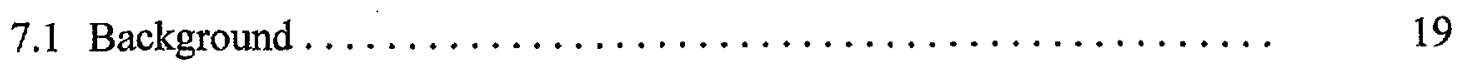

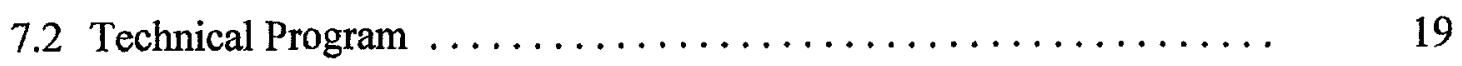

7.2.1 ARIANE .............................. 19

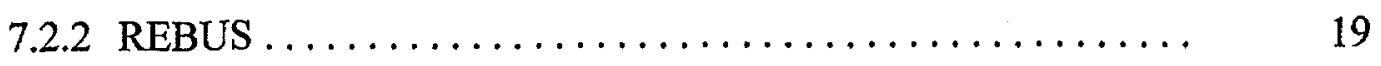

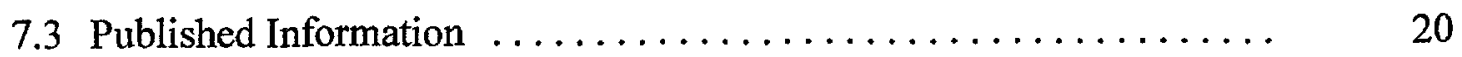

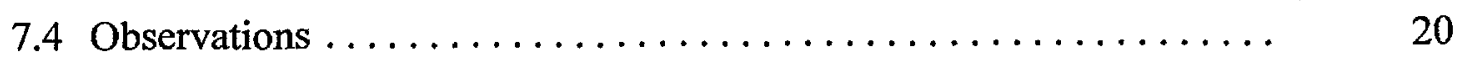

8. OTHER POSSIBLE SOURCES OF VALIDATION $\ldots \ldots \ldots \ldots \ldots \ldots . . \ldots 21$

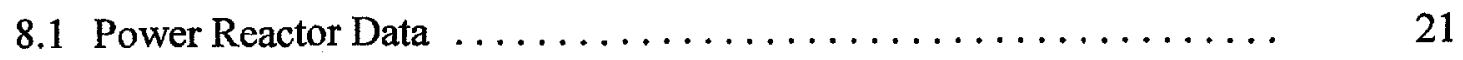

8.2 LWR-PROTEUS Reactor Physics Experiments on High

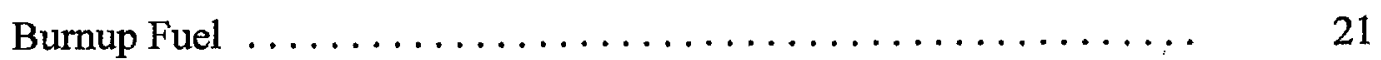

8.3 DOE PIE Program $\ldots \ldots \ldots \ldots \ldots \ldots \ldots \ldots \ldots \ldots \ldots \ldots \ldots \ldots \ldots \ldots, 22$

9. DISCUSSION OF EXPERIMENTS IN RELATION TO US BUC VALIDATION REQUIREMENTS $\ldots \ldots \ldots \ldots \ldots \ldots \ldots \ldots \ldots \ldots, 22$

10. CONCLUSIONS $\ldots \ldots \ldots \ldots \ldots \ldots \ldots \ldots \ldots \ldots \ldots \ldots \ldots \ldots \ldots \ldots \ldots \ldots \ldots, 28$

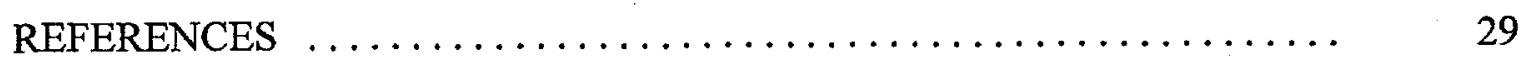




\section{LIST OF FIGURES}

Page

1. The positions of pins extracted from assembly HJX after two cycles of

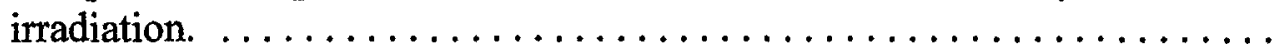

2. The positions of pins extracted from assembly FFPOOHJX after three cycles of irradiation.

3. Summary of PIE Data for PWR UO2 Fuel.

4. Summary of PIE Data for BWR UO2 Fuel.

5. Summary of PIE Data for MOX Fuel.

\section{LIST OF TABLES}

1. French Experimental Basis for Qualification of Irradiated Nuclear Fuel. . .

2. (C-E)/E Values of Isotopic Ratios in Bugey $3 \mathrm{UO}_{2}$ Fuel $(40 \mathrm{GWd} / \mathrm{t}) . \ldots$

3. (C-E)/E (\%) Values for Isotopic Ratios of $\mathrm{UO}_{2}$ Fuel in Gravelines 3. .... 
THIS PAGE INTENTIONALLY LEFT BLANK 


\section{INTRODUCTION}

The application of Burnup Credit (BUC) to criticality safety analyses for Spent Nuclear Fuel (SNF) requires the implementation of both Reactor Physics and Criticality methodologies. In the Reactor Physics domain, tools have been developed and tested over many years and for many reactor systems to allow accurate predictions of reactivity loss with burnup in the reactor core.

Tools to calculate the reactivity of SNF outside the reactor in 'cold' storage, transport or disposal conditions are less well validated. In addition, since SNF operations outside the reactor are made without precise reactivity monitoring equipment and without an automatic SCRAM system, more reliance is placed on the accuracy of calculated safety margins. For these reasons there is a strong requirement for validation of the BUC methodology.

In Europe (particularly in France and the United Kingdom), where reprocessing of SNF is still a central element of the nuclear power program, technical issues associated with the 'back-end' of the fuel cycle have been given high priority. This led to the establishment of several experimental programs aimed at providing data for the validation of both depletion and spent fuel reactivity calculation tools. In Japan too, there has been continued interest in the utilization of spent fuel leading to well funded experimental programs.

In the USA current validation requirements fall into 3 main categories; spent fuel pool, interim storage \& transport casks and disposal. Current validation of spent fuel pool methodology is based mainly on fresh fuel critical experiments. An additional allowance (5\% of the reactivity loss with burnup) to cover uncertainties in burnup effects is imposed. Validation of a proposed 'Actinide-Only' methodology for BUC applied to the transport of PWR fuel is presented in a US DOE Topical Report. This is based mainly on critical experiments for fresh UO2 and MOX fuel and on PIE data for various fuel with initial enrichments up to $3.9 \mathrm{w} / \mathrm{o}$ and irradiations up to $46 \mathrm{GWd} / \mathrm{t}$. An important feature of the methodology is the use of fission product margin to offset uncertainties associated with unusual variations in axial profile and control rod insertion patterns. Currently, the methodology has not been approved, and the USNRC have issued an Interim Staff Guidance (ISG-8 Rev. 1) covering PWR UO2 fuel up to 40GWd/MTU. A Topical Report has also been submitted in support of the criticality assessment for the Yucca Mountain repository. Validation for this methodology is required to cover both actinide and fission product BUC.

In support of efforts to maximize the validation of proposed BUC methodologies in the USA, ANL, supported by AEA Technology, have carried out an extensive review of relevant experiments in Europe and Japan. The aim is to identify experiments that might be used to fill gaps in, or extend the existing US validation database. As well as reviewing the technical content of the experiments, commentary is also given on the current availability of the data (many of the European programs are commercially protected). The results of this review are presented in Section 2. 


\section{SUMMARY OF EXPERIMENTS REVIEWED}

A summary of the experiments reviewed is presented in the Table below.

\begin{tabular}{|c|c|c|c|}
\hline Program & Main Participants & Key Data & Commercial Status \\
\hline French PIE Data & $\begin{array}{l}\text { CEA, EDF, } \\
\text { Framatome, } \\
\text { COGEMA }\end{array}$ & $\begin{array}{l}\text { Spent fuel isotopics (actinides } \\
\text { and fission products). Up to } 4.5 \\
\text { w/o and } 62 \mathrm{GWd} / \mathrm{t}\end{array}$ & Proprietary \\
\hline $\begin{array}{l}\text { French VALDUC } \\
\text { experiments }\end{array}$ & $\begin{array}{l}\text { CEA, IPSN, } \\
\text { COGEMA, }\end{array}$ & $\begin{array}{l}\text { Actinide and Fission Product } \\
\text { cross-section validation. }\end{array}$ & Proprietary \\
\hline CERES & $\begin{array}{l}\text { CEA, UKAEA, } \\
\text { COGEMA, } \\
\text { BNFL, USDOE }\end{array}$ & $\begin{array}{l}\text { Isotopics (actinides and fission } \\
\text { products). Cross-section } \\
\text { validation in various neutron } \\
\text { spectra (global actinide, global } \\
\text { fission product, individual } \\
\text { fission products). Reactivity } \\
\text { worth of spent fuel samples in } \\
\text { various spectra. }\end{array}$ & Proprietary \\
\hline $\begin{array}{l}\text { JAERI BUC } \\
\text { experiments }\end{array}$ & JAERI & $\begin{array}{l}\text { Isotopics (collection of public } \\
\text { domain data - SFCOMPO). } \\
\text { Spent fuel reactivity (PWR and } \\
\text { BWR sub-critical experiments). } \\
\text { Individual 'fission product' } \\
\text { cross-sections (natural } \mathrm{Sm}, \mathrm{Nd} \text {, } \\
\mathrm{Gd}, \mathrm{Rh}, \mathrm{Cs} \text { ). }\end{array}$ & $\begin{array}{l}\text { Assumed to be } \\
\text { 'open' but currently } \\
\text { insufficient data } \\
\text { available in public } \\
\text { domain to } \\
\text { benchmark spent } \\
\text { fuel and fission } \\
\text { product experiments. }\end{array}$ \\
\hline $\begin{array}{l}\text { ARIANNE \& } \\
\text { REBUS }\end{array}$ & $\begin{array}{l}\text { Broad-based } \\
\text { international } \\
\text { programs led by } \\
\text { BelgoNucleaire }\end{array}$ & $\begin{array}{l}\text { Isotopics (extensive range of } \\
\text { fuel types, enrichments, } \\
\text { burnups). Spent fuel reactivity } \\
\text { (fuel substitution). }\end{array}$ & $\begin{array}{l}\text { Currently } \\
\text { proprietary, but } \\
\text { expected to become } \\
\text { public at some } \\
\text { stage ( } \sim 3 \text { years } \\
\text { after completion?) }\end{array}$ \\
\hline $\begin{array}{l}\text { LWR-PROTEUS } \\
\text { Phase II }\end{array}$ & PSI, Swiss utilities & $\begin{array}{l}\text { Isotopics ( } 17 \text { actinides, } 17 \\
\text { fission products). Reactivity } \\
\text { worth of spent fuel samples in } \\
\text { various spectra. }\end{array}$ & Proprietary \\
\hline
\end{tabular}

Following detailed review of the experiments listed above, other possible sources of validation, mainly from power reactor data, are discussed in Section 3.

CEA: Commissariat a $l^{\prime}$ Energie Atomique, France

EDF: Electricite ${ }^{\prime}$ de France, France

COGEMA: Campagnie Generale des Mateiries Nucleaires, France

UKAEA: United Kingdom Atomic Energy Authority, UK

BNFL: $\quad$ British Nuclear Fuel Limited, UK

IAERI: Japan Atomic Energy Research Institute, Japan

PSI: $\quad$ Paul Sherrer Institute, Switzerland 


\section{FRENCH POST IRRADIATION EXAMINATION (PIE) DATA}

\subsection{Background}

The reprocessing of spent nuclear fuel in the French nuclear fuel cycle led to the early development and application of nuclear data and codes for determination of spent fuel inventories and criticality states. Complementary isotopic measurement programs were also instituted to provide data against which the accuracy of the codes could be evaluated. The decision to use mixed oxide fuel (MOX) additionally reinforced the needs for these activities and also led to the development of additional databases that complemented those originally obtained for uranium oxide (UOX) fuel. The experimental programs were conducted by the French Commissariat a l'Energie Atomique (CEA), and were sometimes done in collaboration with Electricite de France (EDF), Framatome, and COGEMA. Some of these programs are currently ongoing. Generally, the programs involve the chemical analyzes of actinide and fission product (FP) nuclides in spent fuel and in certain cases the subsequent reactivity worth measurements of the various burnup credit (BUC) nuclides in the MINERVE reactor by an oscillation technique. The following sections summarize the information currently available to us on the French post-irradiation examination (PIE) data that could be used for validating codes used in BUC analysis. When available, data from these programs are reported in the open literature generally in terms of calculation/experiment $(\mathrm{C} / \mathrm{E})$ values, for specific calculation schemes. Such published information is insufficient to reconstruct the experimental data which are proprietary.

\subsection{Rationale for the French Program}

There exist important differences between the French and US approaches to reactor physics, which help explain why the French have developed a more in-depth experimental program:

- In France, reactor physics and nuclear criticality safety are considered, to a large extent, to be the same discipline and attempt to share the same data libraries and codes.

- Up to the mid 1980 's, the French codes and data libraries were developed with the priority given to the precision of results rather than to the more fundamental quality of the data and algorithms. Effectively, data adjustments were allowed to compensate for algorithmic weaknesses. This situation was acceptable for a static nuclear program. Nevertheless, new challenges which were at that time envisioned in the French nuclear program (MOX and potential MOX reprocessing; $\mathrm{MOX}$ multi-recycle; high burnup $\mathrm{UO}_{2}$; burnup credit in reprocessing plants), prompted the French nuclear establishment to launch a large physics-based code and data development and validation program, aimed at obtaining high quality predictions without using adjustments and compensation of errors.

The resulting French program has four major elements:

- The nuclear data program, integrated within the European JEF project, has put a major effort on validating the best nuclear data evaluations available. Thus, the files it produces 
(currently $\mathrm{JEF}^{1}{ }^{1}$, and $\mathrm{JEFF}^{2}$ in the future) are delivered with a well-established measure of their intrinsic accuracy.

- The code development program has produced state-of-the-art deterministic and stochastic codes.

- The experimental program has produced both "clean" physics measurements (e.g., the CERES program), and representative "mockup" experiments.

- An intense validation effort is still being run, based on a methodology that attempts to differentiate the sources of errors (data, algorithm, and modelling) rather than only analyzing $\mathrm{C} / \mathrm{E}$ 's.

\subsection{Chemical Analysis Programs}

The available French experimental data can be generally classified into the following two groups:

1. Solution samples of entire assembly dissolution obtained from reprocessing plants. A lot of these measurements have been performed in France by COGEMA. However, the unavailability of the exact irradiation histories of the assemblies and the fact that dissolutions are performed over batches of several assemblies limit the usefulness of these data for code validation. Note also that these data remain proprietary, though COGEMA has recently indicated that they might be ready to negotiate the release of certain measurements. In general, it is not believed that these data would be very useful to the US program, except in a statistical sense (trending analyses). Nevertheless, special dissolutions have occurred, for example for homogeneous batches, which might have value.

2. Small fuel pin samples from various axial locations of fuel assemblies. This group of data provides information for the investigation of local irradiation effects. The collection of the data is generally expensive and requires lengthy procedures, and hence only limited data of this type is available. The data are however very accurate and are very useful for nuclear data and code validation. It is this group of data this is emphasized in the following sections.

Table 1 provides a summary of the main experimental programs that have been carried out in France on irradiated UOX and MOX PWR fuel. A significant fraction of these experiments were performed after 1991. The experiments developed for validating burnup credit calculations in the MOX fuel cycle were started in 1996. It is anticipated that this latter program will be sufficient for burnup credit in the MOX fuel cycle by 2000 .

Typically in these programs, the uranium, plutonium, americium, and curium nuclides in the samples are analyzed. Additionally for a few experiments (Table 1), fission product chemical

\footnotetext{
${ }^{\mathrm{I}} \mathrm{JEF}=$ Joint Evaluated File

${ }^{2} \mathrm{JEFF}=$ Joint Evaluated Fission and Fusion File
} 
elements ( $\mathrm{Sm}, \mathrm{Rh}, \mathrm{Nd}, \mathrm{Cs}, \mathrm{Mo}, \mathrm{Eu}, \mathrm{Gd}, \mathrm{Ag}, \mathrm{Ru})$ have also been measured relative to ${ }^{238} \mathrm{U}$, as well as their isotopic composition. Fourteen fission products are typically of interest in the

French burnup credit analyses. These correspond to the most absorbing, stable and nonvolatile nuclides. The ${ }^{155} \mathrm{Eu}$ isotope is also investigated in order to check ${ }^{155} \mathrm{Gd}$ buildup.

For the programs summarized on Table 1, the chemical analyses are done on pin cuts at various heights along the fuel pin in order to investigate the axial temperature and water density effects. In addition, various pins are studied inside the assembly to emphasize the radial effect due to the local spectrum.

\subsubsection{UO2 Programs}

The initial enrichments for the $\mathrm{UO}_{2}$ fueled cores range from 2.6 to $4.5 \%{ }^{235} \mathrm{U}$ and the burnup range from 10 to $62 \mathrm{GWd} / \mathrm{t}$.

The Bugey-3 reactor is a 900 MWe PWR typical of the French nuclear power network and of its standard core management scheme. The core uses $17 \mathrm{X} 17$ rods in the assembly, with Zircaloy cladding. The rods analyzed in the Bugey-3 program belong to two assemblies in which the initial enrichments were respectively $2.1 \%$ and $3.1 \%$. The maximum burnup in this program is about $40 \mathrm{GWd} / \mathrm{t}$ ( 3 cycles).

The Fessenheim-2 (2-cycle irradiation) is the first French experimental program using $17 \mathrm{X} 17$ standard French fuel. The program addressed the calculation problem linked to burnable poison use (pyrex rods during the first cycle) in such cores. Samples from various rods in an assembly were analyzed to provide a good representation of the entire power map. The maximum burnup is relatively low and hence, other experimental programs were performed to permit code validation at higher burnups. An example of this is the samples employed in the Fessenheim-2 (4 and 5 cycle irradiations) measurements. Here, using a higher $\mathrm{UO}_{2}$ fuel enrichment of $3.1 \%{ }^{235} \mathrm{U}$, samples with burnups in the $45 \mathrm{GWd} / \mathrm{t}$ to $60 \mathrm{GWd} / \mathrm{t}$ range were obtained and analyzed.

The Gravelines program enables validation of the calculation schemes for high burnup (five irradiation cycles) fuel and high cycle length operation. The initial $\mathrm{UO}_{2}$ fuel enrichment in the reactors is $4.5 \%$. This experimental program is the most important done to date in France on $900 \mathrm{MWe}$ PWR fuel. In addition to the classical analyses on solution samples using massspectrometry, accurate radial distributions of some main isotopes or chemical elements were obtained directly on a slice of irradiated pellet by new experimental techniques (secondary ion mass spectroscopy (SIMS) and electron-microprobe measurements along the radius of the pellets). Note that one irradiation cycle in the Gravelines program did incorporate Gadolinium burnable poisons.

The Tihange-1 program is of particular note because it is the first in France in which the fuel pins used Zircaloy as the cladding material. Fuel samples were chosen in this program to allow the study of different effects such as variations of axial water density and the radial local spectrum at assembly heterogeneities $\left(\mathrm{UO}_{2}\right.$ rods next to and at the corner of water holes, guide tubes, etc). Additionally, chemical analyses were performed on concentric rings of the fuel pellet in order to investigate the "rim" effect. 
The Cruas-4 program is devoted to the validation of the URT (reprocessed uranium) fuel, using reprocessed then enriched uranium. The program permits validation of ${ }^{236} \mathrm{U}$ capture and provides minor actinide fractions which lead to penalties in the fuel cycle ${ }^{238} \mathrm{Pu}$ for reprocessing; ${ }^{237} \mathrm{~Np}$ for waste storage (T1/2=2.14E+06 years); and ${ }^{232} \mathrm{U}$ for fuel manufacturing, with its two high energy gamma emitting daughters $\left({ }^{208} \mathrm{Tl}\right.$ and $\left.{ }^{212} \mathrm{Bi}\right)$.

\subsubsection{MOX Programs}

The St. Laurent B1 and B2 and Gravelines-4 PWR programs are relatively recent ones devoted to MOX issues. These programs enable extension of the validation basis for nuclear data and codes used for analyzing MOX fuel.

In the St Laurent program, MOX assemblies include three zones with different plutonium enrichments. Various samples were taken from these three zones, after one to three irradiation cycles. The highest burnup in this program is about $45 \mathrm{GWd} / \mathrm{t}$. The burnup in the ongoing Gravelines-4 program is expected to be slightly higher, about $50 \mathrm{GWd} / \mathrm{t}$.

Figures 1 and 2 provide the locations of the irradiated samples for the St. Laurent B1 experiments for two and three irradiation cycles. The burnup in the central locations is roughly $25 \mathrm{GWd} / \mathrm{t}$ for two cycles and $40 \mathrm{GWd} / \mathrm{t}$ for three cycles.

The analysis of MOX irradiations provides information complementary of the $\mathrm{UO}_{2}$ measurements:

- It provides accurate information on the higher Pu isotopics. This information is difficult to extract from $\mathrm{UO}_{2}$ irradiations.

- It provides information for harder spectra.

\subsubsection{BWR Fuel Programs}

In addition to the UOX and MOX experimental programs for PWRs, there is a program underway devoted to BWR burnup credit issues in the MINERVE reactor. It is planned that radial cuts from GE $9 \times 9$ assemblies, irradiated to about $40 \mathrm{GWd} / \mathrm{t}$, will be chemically analyzed and used in the experiments.

\subsubsection{Other Fuel Analysis Programs}

Additional experiments in which simulated fuel pins, representative of previously irradiated pins, are further irradiated in experimental reactor cores (Sherwood, GEDEON and Icare programs), have also been performed. See summary on Table 1. These experiments are usually difficult to analyze and only provide confirmatory information. The GEDEON experiments consist of irradiation of PWR assemblies with a pattern of Gadolinium pins. They have been used to validate depletion calculations for the $\mathrm{Gd}$ pins and assembly power maps. 


\subsection{Code and Data Validation}

The programs discussed above have been developed to provide very accurate inventories of the isotopic compositions of irradiated fuel samples and hence provide clean data against which nuclear data and codes could be validated. The current CEA neutronic code development effort is focussed on the APOLLO2 multigroup (transport) code using JEF2 data. The code, which provides an accurate description of physical phenomena, is used for flux and burnup calculations. The code additionally allows heterogeneous assembly calculations using the Pij collision probability method, and core calculations using discrete ordinate techniques. APOLLO2 offers several options for the physical modelling of resonance self-shielding effects in order to improve resonant reaction rate calculation. The code additionally allows the treatment of the Dancoff effect between different materials and/or resonant nuclide concentrations. With this approach, very accurate representations of the "rim effect" and Pu buildup can be obtained. The APOLLO2 code has a 172-group library based on the most recent evaluations in the Joint European basic nuclear data file, JEF2. The APOLLO library is currently being benchmarked against specific French integral experiments.

As an indication of the high quality experimental measurements of the isotopic inventory and the accuracy of the APOLLO2 code, we present the following results available in the open literature. The first pertains to the Bugey-3 program, in which the assemblies of interest have been irradiated during three cycles. Some of the fuel rods were irradiated for 1.5 cycles (and extracted), others for 2 cycles (and extracted) and others for 3 cycles. The rods extracted after 1.5 cycles were replaced by $1.8 \%$ enriched fuel rods. Those extracted after 2 cycles were replaced by stainless steel rods. Due to the expensive computational cost of a full-assembly APOLLO2 calculation using the exact collision probability option, alternate schemes using the multicell method (based on the interface-current formulation) were developed. The best approximate scheme (called UP1) uses the linear-anisotropic interface-current approximation to couple the cells. In the Bugey-3 analysis, special attention was also given to modelling the self-shielding for pins close to water holes and to obtain accurate representation of the radial resonant absorption in the fuel pin. Typical $\mathrm{C} / \mathrm{E}$ values obtained for the $\mathrm{UO}_{2}$ fuel samples from the Bugey-3 reactor is shown in Table 2. The results on Table 2 indicate that the buildup of ${ }^{239} \mathrm{Pu}$ and other higher actinides are accurately predicted by the code. The fact that

${ }^{241} \mathrm{Pu}$ and ${ }^{242} \mathrm{Pu}$ are underestimated by APOLLO2 may indicate that the capture cross-section of ${ }^{239} \mathrm{Pu}$ is low in the $0.3 \mathrm{eV}$ resonance.

Table 3 shows the results of comparison of calculation-to-experiment isotopic ratios (usually to ${ }^{238} \mathrm{U}$ ) for pins at mid-core height in Gravelines-3. The calculated values are obtained with the CESAR depletion code, which originated from the APOLLO1 code. While the C/E ratios are generally very good, results with the APOLLO2 code are expected to be better.

Information available for the MOX program indicates generally low uncertainties in the radiochemical assaying process. The maximum value of the 1-sigma experimental uncertainties for uranium, plutonium, neodymium, cesium, americium, and curium isotopes is about $2.5 \%$, which is considered to be very good. Uncertainties in the primary heavy isotopes ${ }^{235} \mathrm{U},{ }^{239} \mathrm{Pu},{ }^{240} \mathrm{Pu},{ }^{241} \mathrm{Pu}$ and ${ }^{242} \mathrm{Pu}$ ) are generally less than $0.5 \%$. As additional 
indication of the excellent quality of the measurement data, comparison of the measured and APOLLO2 calculated isotopic ratios show generally good agreement (throughout the burnup range) for the primary heavy isotopes and Nd (typically less than 5\%). Higher differences were observed for some of the other isotopes.

\subsection{Published Information}

A paper describing the French PIE program and summarizing the $\mathrm{C} / \mathrm{E}$ results was presented at PHYSOR'96 [1]. Additional information on these experiments was also obtained from the proceedings of the criticality safety meetings held in Chelan Washington [2]. The GEDEON experiments were summarized in a paper presented at the 1987 Topical Meeting on Advances in Reactor Physics, Mathematics and Computation held in Paris [3].

\subsection{Observations}

The French PIE programs offer valuable data that could be used in the validation of nuclear data and codes used burnup credit calculations. The experiments are generally of high quality and have very low experimental uncertainties, and measured data are well documented. (The variables that affect the isotopic inventory of irradiated fuel have been accurately recorded, as indicated by the good estimate of the inventory by the APOLLO2 code.) The experimental data are particularly useful because they contain some fuel-pin measurements with initially high enrichment levels $(4.5 \% 235 \mathrm{U})$ and some that are irradiated to relatively high burnup values $(60 \mathrm{GWd} / \mathrm{t})$. Furthermore, the MOX cases are complementary of the $\mathrm{UO}_{2}$ cases because they provide additional basis for the validation of $\mathrm{Pu}$ and other higher actinide data.

Other experimental measurements concerning stainless-steel-clad fuel pins have also been performed for fuel from the CNA nuclear power station located in the Ardennes, France. 
Table 1. French Experimental Basis for Qualification of Irradiated Nuclear Fuel

\begin{tabular}{|c|c|c|c|c|}
\hline Reactor & Assembly Type & $\begin{array}{c}\text { Fuel } \\
\text { Enrichment(s) } \\
(\%)\end{array}$ & $\begin{array}{l}\text { Fuel Burnup } \\
(\mathrm{GWd} / \mathrm{t})\end{array}$ & $\begin{array}{c}\text { Available } \\
\text { Experimental } \\
\text { Data }\end{array}$ \\
\hline \multicolumn{5}{|l|}{ POWER REACTORS } \\
\hline $\begin{array}{c}\text { Bugey } 3 \\
\text { Cycles } 1 \text { to } 3\end{array}$ & $\begin{array}{l}\text { 17X17 PWR, } \\
\text { UOX }\end{array}$ & $\begin{array}{l}2.10 \\
3.10\end{array}$ & $\begin{array}{c}20 \\
19 \text { to } 38\end{array}$ & $\begin{array}{l}\mathrm{HI}, \mathrm{MA}, \mathrm{Nd}, \mathrm{Cs} \\
\text { BUC. } \\
\text { OSIM }\end{array}$ \\
\hline $\begin{array}{l}\text { Fessenheim } 2 \\
\text { Cycle } 2\end{array}$ & $\begin{array}{c}\text { 17X17 PWR, } \\
\text { UOX }\end{array}$ & 2.60 & 27 to 30 & $\mathrm{HI}, \mathrm{Am}, \mathrm{Nd}$ \\
\hline $\begin{array}{l}\text { Fessenheim } 2 \\
\text { Cycles } 4 \text { and } 5\end{array}$ & 17X17 PWR UOX & 3.10 & 45 to 60 & $\begin{array}{l}\mathrm{HI}, \mathrm{Am} \\
\text { OSIM }\end{array}$ \\
\hline $\begin{array}{l}\text { Gravelines } 3+2 \\
\text { Cycles } 2 \text { to } 5\end{array}$ & 17X17 PWR UOX & 4.50 & 25 to 62 & $\begin{array}{l}\mathrm{HI}, \mathrm{Am}, \mathrm{Nd}, \mathrm{Cs} \text {, } \\
\text { BUC, SIMS, } \\
\text { microprobe } \\
\text { OSIM }\end{array}$ \\
\hline $\begin{array}{l}\text { Cruas 4/URT } \\
\text { Cycles } 1 \text { to } 4\end{array}$ & 17X17 PWR UOX & $\begin{array}{c}3.61 \\
\mathrm{U} 6 / \mathrm{U} 8=1.2 \%\end{array}$ & $\begin{array}{c}11 \text { to } 34(\mathrm{D}) \\
45(\mathrm{P})\end{array}$ & $\mathrm{HI}, \mathrm{Nd}$ \\
\hline $\begin{array}{l}\text { Tihange } 1 \\
\text { Cycles } 1 \text { to } 3\end{array}$ & 15X15 PWR UOX & 3.10 & 10 to 40 & $\mathrm{HI}, \mathrm{Am}, \mathrm{Nd}$ \\
\hline $\begin{array}{l}\text { St. Laurent B1 } \\
\text { Cycles } 1 \text { to } 3 \\
\text { (samples in } 3 \\
\text { zones) }\end{array}$ & 17X17 PWR MOX & $\begin{array}{l}\text { U approx. } 0.22 \% \\
\mathrm{Pu} /(\mathrm{Pu}+\mathrm{U})=4.5 \%\end{array}$ & 10 to 45 & $\begin{array}{l}\mathrm{HI}, \mathrm{Am}, \mathrm{Nd}, \mathrm{Cs} \\
\text { BUC, SIMS, } \\
\text { microprobe } \\
\text { OSIM }\end{array}$ \\
\hline $\begin{array}{l}\text { Gravelines } 4 \\
3 \text { to } 4 \text { cycles }\end{array}$ & 17X17 PWR MOX & Same as above & 35 to 50 & $\mathrm{HI}, \mathrm{Nd}$ \\
\hline $\begin{array}{l}\text { St. Laurent B2 } \\
3 \text { cycles } \\
\text { (sample from } \\
\text { central zone) }\end{array}$ & 17X17 PWR MOX & Same as above & 45 & $\begin{array}{l}\mathrm{HI}, \mathrm{Am}, \mathrm{Cs} \text {, } \\
\text { microprobe } \\
\text { OSIM }\end{array}$ \\
\hline \multicolumn{5}{|c|}{ EXPERIMENTAL REACTORS } \\
\hline $\begin{array}{l}\text { Sherwood } 1 \\
\text { Melusine }\end{array}$ & $\begin{array}{l}\text { Simulation of } \\
\text { PWR UO }_{2} \text { doped } \\
\text { with NL }\end{array}$ & $\begin{array}{l}\text { U5/U8 }=2.8 \% \\
\text { Variable base }\end{array}$ & $\begin{array}{c}1.1\left(\mathrm{UO}_{2} \text { in }\right. \\
\text { central zone) }\end{array}$ & $\begin{array}{l}\text { Resulting daughter } \\
\text { isotopes of } \mathrm{HI}, \mathrm{Nd}\end{array}$ \\
\hline $\begin{array}{l}\text { Sherwood } 2 \\
\text { Melusine }\end{array}$ & $\begin{array}{l}\text { Simulation of } \\
\text { PWR UO }_{2} \text { doped } \\
\text { with }{ }^{236} \mathrm{U}\end{array}$ & $\begin{array}{c}\text { U5/U8 }=2.80 \% \\
0.1<\text { U6/U8 }<1.2 \%\end{array}$ & $\begin{array}{l}2.5\left(\mathrm{UO}_{2} \text { in }\right. \\
\text { central zone })\end{array}$ & Same as above \\
\hline $\begin{array}{l}\text { Gedeon } 1 \\
\text { Melusine }\end{array}$ & $\begin{array}{l}\text { Simulation of } \\
\mathrm{PWR} \mathrm{UO}_{2} / \mathrm{UO}_{2}^{-} \\
\mathrm{Gd}_{2} \mathrm{O}_{3}\end{array}$ & $\begin{array}{l}\mathrm{UO}_{2} 3.25 \% \\
\quad \mathrm{Gd} 5 \%\end{array}$ & 3.0 to $10\left(\mathrm{UO}_{2}\right)$ & $\mathrm{HI}, \mathrm{Nd}, \mathrm{Gd}$ \\
\hline $\begin{array}{l}\text { Gedeon } 2 \\
\text { Melusine }\end{array}$ & $\begin{array}{l}\text { Simulation of } \\
\text { PWR } \mathrm{UO}_{2} / \mathrm{UO}_{2-}^{-} \\
\mathrm{Gd}_{2} \mathrm{O}_{3}\end{array}$ & $\begin{array}{l}\mathrm{UO}_{2} 3.25 \% \\
\quad \mathrm{Gd} 8 \%\end{array}$ & 3.5 to $13\left(\mathrm{UO}_{2}\right)$ & $\begin{array}{l}\text { HI, Nd, Gd } \\
\text { OSIM }\end{array}$ \\
\hline $\begin{array}{c}\text { Icare } 1 \text { and } 2 \\
\text { Melusine }\end{array}$ & $\begin{array}{c}\text { Simulation of shift } \\
\text { moderator reactor } \\
\mathrm{UO}_{2} \text { doped with } \\
\mathrm{U}, \mathrm{Pu} \text { and FP }\end{array}$ & $\begin{array}{c}\text { Base-UO } \mathrm{U}_{2} 0.5 \% \\
\text { Lattice-MOX } 8.5 \%\end{array}$ & 1.2 (lattice) & $\begin{array}{l}\text { Resulting daughter } \\
\text { isotopes of HI, } \\
\text { Am, FP }\end{array}$ \\
\hline $\begin{array}{c}\text { BWR } \\
\text { Gundremmingen } \mathrm{B}\end{array}$ & 9X9 GE BWR & $3.95 \%$ & $\begin{array}{c}\max \sim 40 \\
15 \text { samples }(\mathrm{P})\end{array}$ & $\begin{array}{l}\text { HI, Am, Nd, BUC } \\
\text { for FP; OSIM }\end{array}$ \\
\hline
\end{tabular}

$\mathrm{HI}=$ heavy isotopes $(\mathrm{U}, \mathrm{Pu}) ; \mathrm{MA}=$ minor actinides $(\mathrm{Np}, \mathrm{Am}, \mathrm{Cm}) ; \mathrm{BUC}=$ burnup credit fission products.

OSIM $=$ oscillation of irradiated sample in the MINERVE facility.

(D) = results are available; $(P)=$ results are pending. 
Table 2. (C-E)/E Values of Isotopic Ratios in Bugey $3 \mathrm{UO}_{2}$ Fuel $(40 \mathrm{GWd} / \mathrm{t}$ )

\begin{tabular}{|c|c|}
\hline Isotopic ratio & (C-E)/E $(\%)$ \\
\hline${ }^{236} \mathrm{U} /{ }^{33} \mathrm{U}$ & 1.0 \\
\hline${ }^{239} \mathrm{Pu} / 38 \mathrm{U}$ & 1.7 \\
\hline${ }^{241} \mathrm{Pu} /{ }^{238} \mathrm{U}$ & 0.6 \\
\hline${ }^{241} \mathrm{Pu} /{ }^{238} \mathrm{U}$ & -3.2 \\
\hline${ }^{242} \mathrm{Pu} / 38 \mathrm{U}$ & 5.0 \\
\hline
\end{tabular}

Table 3. (C-E)/E (\%) Values for Isotopic Ratios of $\mathrm{UO}_{2}$ Fuel in Gravelines 3

\begin{tabular}{|c|c|c|c|c|}
\hline & $\begin{array}{l}2 \text { Cycles } \\
27300 \mathrm{MWd} / \mathrm{t}\end{array}$ & $\begin{array}{l}3 \text { Cycles } \\
39100 \mathrm{MWd} / \mathrm{t}\end{array}$ & $\begin{array}{l}4 \text { Cycles } \\
51600 \mathrm{MWd} / \mathrm{t}\end{array}$ & $\begin{array}{l}5 \text { Cycles } \\
61200 \mathrm{MWd} / \mathrm{t}\end{array}$ \\
\hline $\begin{array}{l}{ }^{234} \mathrm{U} / f^{238} \mathrm{U} \\
{ }^{233} \mathrm{U} /{ }^{238} \mathrm{U} \\
{ }^{236} \mathrm{U} /{ }^{238} \mathrm{U}\end{array}$ & $\begin{array}{l}0.7 \\
-1.3 \\
-0.7\end{array}$ & $\begin{array}{l}1.6 \\
-2.5 \\
-0.7\end{array}$ & $\begin{array}{l}-2.9 \\
-3.6 \\
-1.4 \\
\end{array}$ & $\begin{array}{l}-2.9 \\
-6.8 \\
-0.8\end{array}$ \\
\hline${ }^{237} \mathrm{~Np} /{ }^{238} \mathrm{U}$ & 4.9 & 2.9 & 0.3 & 1.1 \\
\hline $\begin{array}{l}{ }^{238} \mathrm{Pu}{ }^{238} \mathrm{U} \\
{ }^{239} \mathrm{Pu} /{ }^{238} \mathrm{U} \\
{ }^{240} \mathrm{Pu} / 238 \mathrm{U} \\
{ }^{241} \mathrm{Pu} / 238 \mathrm{U} \\
{ }^{242} \mathrm{Pu} /{ }^{238} \mathrm{U} \\
\mathrm{Pu} \text {-total }{ }^{238} \mathrm{U}\end{array}$ & $\begin{array}{l}-5.8 \\
-0.7 \\
-0.8 \\
-4.6 \\
0.65 \\
-1.1\end{array}$ & $\begin{array}{l}-4.7 \\
-0.35 \\
0.0 \\
-3.0 \\
3.1 \\
-0.5\end{array}$ & $\begin{array}{l}-5.9 \\
0.0 \\
0.3 \\
-2.4 \\
3.25 \\
0.2\end{array}$ & $\begin{array}{l}-4.3 \\
0.8 \\
0.6 \\
-1.2 \\
5.3 \\
0.65\end{array}$ \\
\hline${ }^{241} \mathrm{Am} /{ }^{238} \mathrm{U}$ & -11.0 & -3.95 & -10.6 & -5.4 \\
\hline $\begin{array}{l}{ }^{133} \mathrm{Cs} /{ }^{238} \mathrm{U} \\
{ }^{134} \mathrm{Cs} /{ }^{238} \mathrm{U} \\
{ }^{135} \mathrm{Cs}^{238} \mathrm{U} \\
{ }^{137} \mathrm{Cs}{ }^{238} \mathrm{U}\end{array}$ & $\begin{array}{l}-3.0 \\
-19.3 \\
-0.8 \\
-5.8\end{array}$ & $\begin{array}{l}0.3 \\
-13.4 \\
-0.9 \\
-3.3\end{array}$ & $\begin{array}{l}0.1 \\
-10.9 \\
-2.9 \\
-4.0\end{array}$ & $\begin{array}{l}0.7 \\
-5.9 \\
-2.8 \\
-2.55\end{array}$ \\
\hline $\begin{array}{l}{ }^{143} \mathrm{Nd}^{/ 238} \mathrm{U} \\
{ }^{144} \mathrm{Nd} /{ }^{238} \mathrm{U} \\
{ }^{145} \mathrm{Nd} /{ }^{238} \mathrm{U} \\
{ }^{145} \mathrm{Nd} d^{238} \mathrm{U} \\
{ }^{148} \mathrm{Nd} /{ }^{238} \mathrm{U} \\
{ }^{154} \mathrm{Nd} /{ }^{238} \mathrm{U}\end{array}$ & $\begin{array}{l}2.4 \\
-0.2 \\
0.5 \\
2.0 \\
0.0 \\
0.0\end{array}$ & $\begin{array}{l}1.0 \\
-1.0 \\
-1.0 \\
2.2 \\
0.0 \\
1.25\end{array}$ & $\begin{array}{l}1.5 \\
-1.3 \\
-1.8 \\
2.7 \\
0.0 \\
1.4\end{array}$ & $\begin{array}{l}1.4 \\
-1.0 \\
-2.8 \\
3.45 \\
0.0 \\
1.8\end{array}$ \\
\hline $\begin{array}{l}{ }^{95} \mathrm{Mo} o^{238} \mathrm{U} \\
{ }^{99} \mathrm{Tc} \mathrm{c}^{238} \mathrm{U} \\
{ }^{101} \mathrm{Ru} /{ }^{238} \mathrm{U} \\
{ }^{1016} \mathrm{Ru} /{ }^{238} \mathrm{U} \\
{ }^{1113} \mathrm{Rh} /{ }^{238} \mathrm{U}\end{array}$ & $\begin{array}{l}-- \\
- \\
- \\
-1.2 \\
-\end{array}$ & $\begin{array}{l}6.25 \\
3.0 \\
5.6 \\
-5.7 \\
8.0 \\
\end{array}$ & $\begin{array}{l}3.9 \\
7.2 \\
7.2 \\
-0.6 \\
9.0 \\
\end{array}$ & $\begin{array}{l}3.05 \\
9.05 \\
1.75 \\
-0.2 \\
7.1 \\
\end{array}$ \\
\hline $\begin{array}{l}{ }^{147} \mathrm{Sm} /{ }^{238} \mathrm{U} \\
{ }^{149} \mathrm{Sm} /{ }^{238} \mathrm{U} \\
{ }^{150} \mathrm{Sm} /{ }^{238} \mathrm{U} \\
{ }^{151} \mathrm{Sm} /{ }^{238} \mathrm{U} \\
{ }^{152} \mathrm{Sm} /{ }^{238} \mathrm{U} \\
\mathrm{Sm} \text {-total } /{ }^{338} \mathrm{U}\end{array}$ & $\begin{array}{l}- \\
- \\
- \\
- \\
- \\
-\end{array}$ & $\begin{array}{l}-4.8 \\
-2.1 \\
-5.8 \\
20.8 \\
29.9 \\
0.5\end{array}$ & $\begin{array}{l}-- \\
-- \\
-- \\
-- \\
--\end{array}$ & $\begin{array}{l}-3.6 \\
1.9 \\
-8.6 \\
26.7 \\
44.1 \\
1.45\end{array}$ \\
\hline $\begin{array}{l}{ }^{153} \mathrm{Eu} /{ }^{238} \mathrm{U} \\
{ }^{154} \mathrm{Eu} /{ }^{238} \mathrm{U} \\
{ }^{155} \mathrm{Eu} / 238 \mathrm{U} \\
{ }^{155} \mathrm{Eu} /{ }^{238} \mathrm{U}\end{array}$ & $\begin{array}{l}- \\
-2.35 \\
- \\
-\end{array}$ & $\begin{array}{l}-7.8 \\
12.5 \\
10.3 \\
0.8\end{array}$ & $\begin{array}{l}- \\
21.9 \\
- \\
-\end{array}$ & $\begin{array}{l}3.7 \\
37.6 \\
19.2 \\
12.4\end{array}$ \\
\hline
\end{tabular}




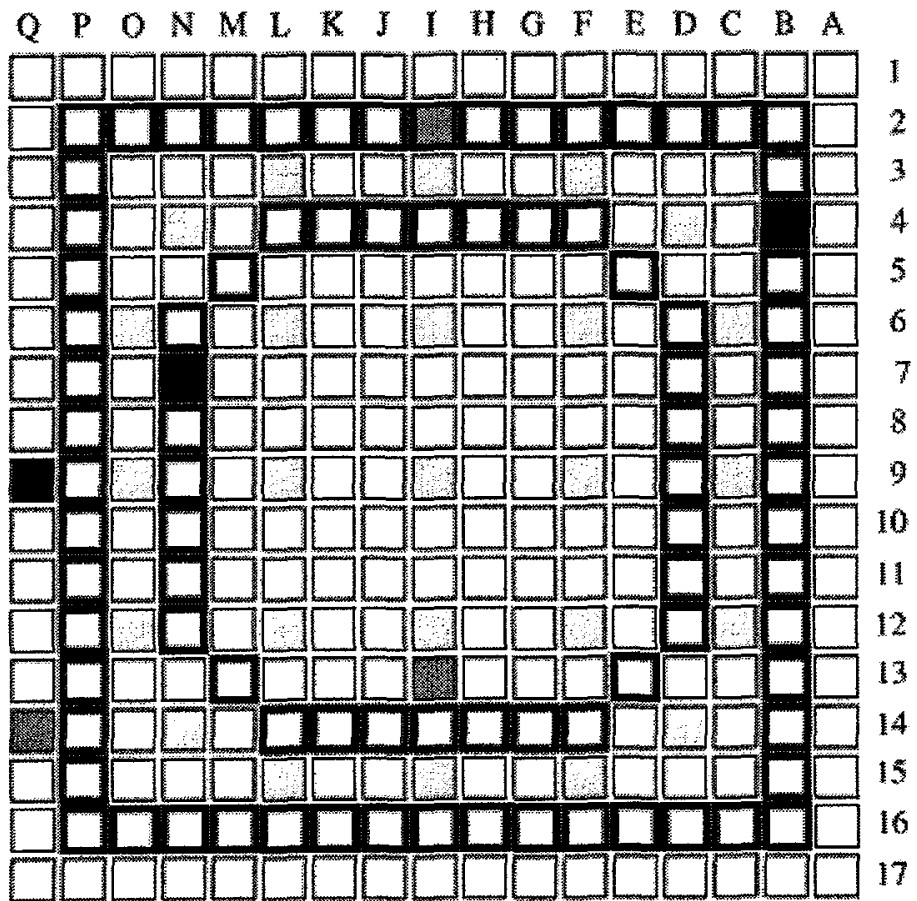

Guide tube

Pin extracted and zanalyzed

Pin extracted but not analyzed

Figure 1. The positions of pins extracted fron assemtly HIX after two cycles of irradiation. 


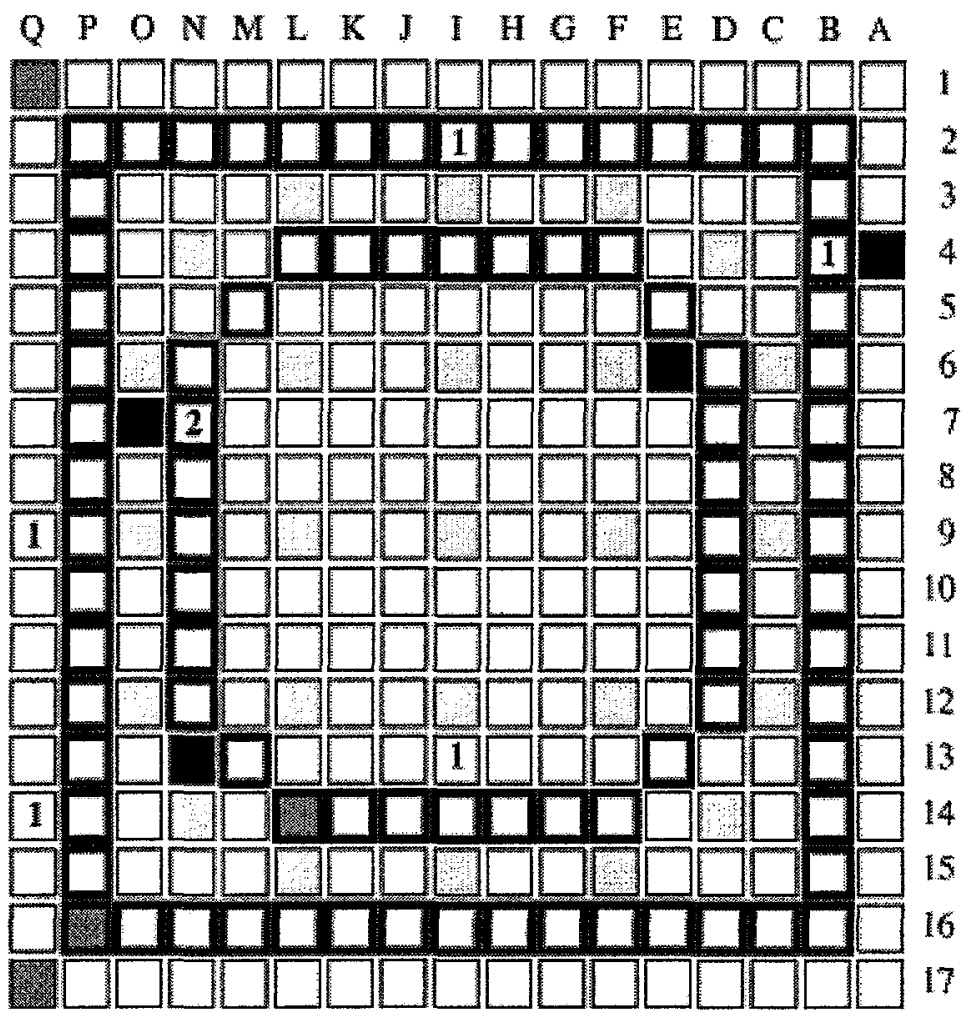

Guide tube

Pin extrated but not analyzed
Pin extracted and analyzed

$\mathrm{x}$ Fin replacing one extracted after two cyeles

Type of replacement fuel pin 1: $\mathrm{VO}_{2}$ enriched to $2.4{ }^{235} \mathrm{U}$

2: MOX with 29\% $\mathrm{Pu}$

Figure 2. The positions of pins extracted from assembly FFPOOHJX after tivee cycles of irradiation. 


\subsection{Background}

The Valduc critical experiments are designed for qualification of absorption cross sections of actinides (U, Pu and $\mathrm{Am}$ ) and fission products (FPs) and the calculation schemes (particularly the self-shielding methodology) used in evaluating them. The experiments are jointly funded by CEA/IPSN and COGEMA and are performed at the Valduc Facility in France. The experiments started in 1987. The first step of the experimental program, called the HTC (High BurnUp) program, concerns U, Pu, and Am nuclides. About 150 experiments of these earlier cases were performed and completed by 1991. These HTC experiments simulated spent fuel with a flat axial profile. The fuel composition of the simulated rods (about 2500) corresponds to a spent fuel with an initial enrichment of $4.5 \%{ }^{235} \mathrm{U}$ and an average burnup of $37.5 \mathrm{GWd} / \mathrm{t}$, but without fission products.

Currently ongoing experiments (step 2), called the fission products program, were started in 1996 and were designed for investigating fission products issues in spent nuclear fuel. These experiments are scheduled to end in 2001 . The goal of the program is to qualify the absorption cross sections of the most important fission products and to extend the scope of the qualification of the French criticality codes. Six primary fission products are of interest, namely ${ }^{103} \mathrm{Rh},{ }^{133} \mathrm{Cs},{ }^{143} \mathrm{Nd},{ }^{149} \mathrm{Sm},{ }^{152} \mathrm{Sm}$, and ${ }^{155} \mathrm{Eu}$. These nuclides are chosen because they are soluble in dissolution liquor. The nuclides also contribute a significant fraction of the total fission-product absorption in spent fuel (about 50\% if xenon and iodine isotopes are excluded). The first five of the nuclides are stable, and the sixth forms ${ }^{155} \mathrm{Gd}$ with a half-life of 4.7 years. It is expected that the fission product experiments will allow COGEMA and TRANSNUCLEAIRE to take credit for these fission products in their criticality evaluations. The focus in the following sections is on these latter Valduc fission-product experiments.

\subsection{Fission Product Experimental Program}

The experimental program is approached systematically in three steps, in order to differentiate the various self-shielding issues. The three steps are classified as (a) physical experiments, (b) dissolution experiments, and (c) global experiments. The experiments are performed in the pool of the "Apparatus B" of the Valduc facility, and use subcritical approaches to criticality. The variables in these experiments are typically the concentration of the solution filling an inner $\mathrm{Zr}$ tank, and the driver rod pitch.

\subsubsection{Physical Experiments}

The aim of these experiments is the qualification of the individual fission product absorption in a dissolution liquor. The experimental setup could also be used to study the absorption of mixed fission products, but this is only planned for the future. In the experimental setup, a square pitch array of $\mathrm{UO}_{2}\left(4.742 \%{ }^{235} \mathrm{U}\right)$ driver rods surrounds a small $\mathrm{Zr}$ tank filled with an aqueous nitric acid solution of the fission product. The experimental pool containing the $\mathrm{Zr}$ tank and the driver rods is filled incrementally with water, the height of which is the parameter of the subcritical approach. The water acts both as moderator and reflector in the experiment. At the time the technical paper describing these experiments was written (J. Anno et al., 1997), only the experiments for ${ }^{149} \mathrm{Sm}$ had been completed. It was anticipated that the experiments for the other five cases would be carried out in 1998 and beyond. 


\subsubsection{Dissolution Experiments}

The dissolution experiments were designed for the study of the absorption of individual or mixed fission products in close interaction with heavy isotopes. For this type of experiment, the central $\mathrm{Zr}$ tank contains an array of $\mathrm{UO}_{2}$ or $\mathrm{HTC}^{3}$ rods and is filled with a nitric acid solution of the fission products. This tank is in turn surrounded by an array of driver $\mathrm{UO}_{2}$ fuel rods; both located in the reactor pool.

\subsubsection{Global Experiments}

The goal of these experiments is to study the absorption of mixed fission products with uranium isotopes in close interaction with the same heavy isotopes (uranium) and other isotopes (plutonium and americium). In the experimental setup for this case, the $\mathrm{Zr}$ tank contains all the fuel rods $\left(\mathrm{UO}_{2}\right.$ or $\left.\mathrm{HTC}^{*}\right)$ and is filled with a moderating material composed of fission products in a depleted uranyl nitrate solution. (No ex-tank driver rods are employed in these experiments.) Additional studies are being planned to determine the effect of a slab reflector of the depleted uranyl nitrate solutions containing the fission product on the criticality state.

\subsection{Published Information}

A paper describing the French Valduc fission products program was presented by J. Anno et al., at the criticality safety topical meeting held in Chelan, Washington [4]. Another paper was presented by the same group (Anno et al.) during ICNC'95 [5]. A summary paper, with limited new information was presented by Barbry at ICNC'99 [6]. Additional mention to the program was found in an IAEA TECDOC (1998) paper by Chanzy and Guillou [7].

\subsection{Observations}

The fission product experiments at Valduc are currently ongoing. It was stated in one of the papers that the definition and scope of these experiments were limited because of costs and other issues (isotopics, solubility, etc.). As of 1997 , only cases involving ${ }^{149} \mathrm{Sm}$ as the individual fission product had been completed. It is expected that about 32 experiments of all types will be completed by the end of the program. These critical experiments provide additional cases for extending the validation basis of codes used in criticality calculations for burnup credit (either for when a credit is taken for the FPs or when the FPs are used as margins.) The experimental setup however raises the question of how accurately the selfshielding effects in these experiments (fission products are outside the fuel rods) represent those found in various spent fuel configurations. Anno et al. stated that the neutron spectrum is due to the pitches of the driver and central tank arrays, and that this spectrum is similar or close to those found in industrial cases of interest. They observed a very small variation in the energy range over which the FPs absorption occurs, when the driver array pitch is varied. Note that there are ongoing disputes between experts as to the representativity of such experiments.

\footnotetext{
${ }^{3} \mathrm{HTC}=$ Haut Taux de Combustion (High Burnup)
} 
The ICNC '95 paper gives a fairly good detail of the experimental setup, including dimensions of the apparatus and fuel rod pitches. Additional geometrical data can also be found in the 1997 paper. Information on $k_{\text {eff }}$ versus ${ }^{149} \mathrm{Sm}$ concentration in the solution and the rod array configuration (for the dissolution-type experiments) are also presented in the 1997 paper.

\section{CERES}

\section{$5.1 \quad$ Background}

At the PHYSOR'91 Conference in Marseilles papers were presented from the French and UK on measurements to validate calculations of reactivity loss with burnup. Both programs were based around reactivity perturbation measurements on small samples of irradiated fuel in zeropower reactors. This led to a joint program known as CERES by which measurements on PWR, BWR and MOX samples were made in a range of neutron spectra. Additional measurements included samples of 'Actinide-Only' fuel in CERES Phase I and Fission Product samples in Phases II and III. In CERES Phase III the program was extended to include the participation of the US Department of Energy (through Sandia Laboratories), using PWR and BWR fuel samples from the ATM program at Battelle Laboratories.

Data from all phases of the CERES program are currently subject to commercial restriction. Results are reported in the open literature in terms of ' $\mathrm{C} / \mathrm{E}$ ' (calculations/experiment) values.

\subsection{Summary of Technical Program}

\subsubsection{Pre-CERES}

In the UK the techniques used in the CERES programs had been developed over a number of years and had included measurements on irradiated high enrichment samples, AGR ${ }^{4}$ and PWR samples; the main aim of these stages was to validate global fission product cross-sections. In France measurements were made on four irradiated PWR samples and a corresponding set of 'Actinide-Only' samples which matched the uranium and plutonium composition of the four irradiated samples. These samples were re-used in the first phase of CERES for the DIMPLE measurements (see below).

\subsubsection{CERES}

A summary of the experimental program, carried out in the MINERVE and DIMPLE facilities at CEA Cadarache and AEA Technology Winfrith respectively is given below.

Phase I: Irradiated PWR (up to $\sim 60 \mathrm{GWd} / \mathrm{t}$ ), Actinide Only, unirradiated MOX in three DIMPLE assemblies. Irradiation history and spent fuel isotopics for $\mathrm{U} / \mathrm{Pu}$ are provided. The measurements were made in three different assemblies emphasizing epi-thermal, thermal and fission events respectively.

Phase II: Individual fission product absorption was measured for 12 of the Major fission products. Measurements were made in two DIMPLE assemblies, emphasizing epi-thermal and

${ }^{4} \mathrm{AGR}=$ Advanced Graphite Reactor 
thermal events, and one MINERVE assembly, designed to have a spectrum close to a typical PWR.

Phase III: Measurements on fission products were completed. Four ( 2 X PWR +2 X BWR) irradiated samples from the ATM program were measured in two DIMPLE assemblies (thermal and epi-thermal spectra). Destructive PIE on the four samples yielded the isotopic concentration of 12 of the Major Fission products.

The experiment is based on measurements of the reactivity worth of $10 \mathrm{~cm}$ lengths of fuel sample along with a set of calibration samples containing a range of fissile to absorber mixes. The analysis compares the reactivity of the calibration samples with the measured worths of the irradiated, Actinide-Only or Fission Product samples. Experimental uncertainty is of the order of $2 \%$ in the change in reactivity due to burnup (variation of reactivity between calibration samples and experimental samples). Integral fission product reaction rates were also measured to about $2 \%$.

\subsection{Published Information}

Papers describing the CERES program and summarizing the results of analysis have been presented at ICNC'95 [8,9] and PHYSOR'96 [10]. Analyzes using JEF2.2 nuclear data have also been presented to JEF Integral Benchmarking meetings. At this stage some of the results for fission products and the Phase III BWR results are still described as provisional. Definitive results are expected this year. In general analysis based on JEF2.2 nuclear data shows very good agreement for all samples, providing strong evidence that reactivity loss with burnup can be accurately predicted by codes using this data. Some individual fission products showed significant discrepancies, most notably Rh103.

\subsection{Observations}

These experiments have been used both to validate Burnup Credit methodologies and to benchmark the JEF nuclear data file. The experiments are primarily designed to validate the nuclear data used in code schemes. Due to small size of the samples (reactivity worth $-20 \mathrm{pcm}$ ) the analysis is not well suited to Monte-Carlo methods and published results are limited to deterministic methods (APOLLO and WIMS). Work is currently underway to take advantage of recently developed Monte-Carlo methods in MONK to analyze the experiments.

A strong feature of the CERES measurements is the use of measurements in varied neutron spectra and on a range of sample types to permit separation of various contributions to spent fuel reactivity. This provides important diagnostic information needed to understand the underlying physics of the BUC problem and identify any areas of possible cancellation of errors in calculation schemes. 


\section{JAERI BURNUP CREDIT PROGRAM}

\subsection{Background}

The Japanese have been developing a burnup credit program designed to validate methodologies for both PWR and BWR fuels. The program has been co-ordinated under the auspices of the Science and Technology Agency (STA) of Japan since 1994.

There appear to be three main sources of experimental data:

- sub-critical reactivity measurements on spent fuel elements

- critical reactivity measurements on individual fission products

- the 'Spent Fuel Isotopic Compositions Database (SFCOMPO)'

Much of the information derives from studies made by JAERI, particularly the reactivity measurements. SFCOMPO has become an international database, deriving data from several sources (notably the USA) and access to the information through the Internet is now coordinated by the OECD-NEA. Further data will be derived through the ARIANE program (see section 7 below). Since the US is already a participant in the OECD-NEA Burnup Credit program and ARIANE, it is the reactivity measurements that are of most interest in terms of increasing the experimental validation dataset.

\subsection{Technical Program}

\subsubsection{Spent Fuel Reactivity}

The measurements presented at ICNC' 95 consist of sub-critical measurements on single reconstructed PWR elements immersed in water. The experiments were carried out at the Reactor Fuel Examination Facility of JAERI. Two separate measurements are reported, for a 17 X 17 PWR element and a14 X 14 PWR element at 39 and 40GWd/t burnup respectively. The sub-critical $\mathrm{k}$-eff is determined from measurements of the axial decay constant $(\gamma)$ in the presence of a Cf252 neutron source. Two types of scan are made; one with a fixed source and moveable detector and visa versa. Measurements are also made of the axial flux distribution with no source present, to allow correction for the effects of the spontaneous fission source in the spent fuel.

In principle benchmarking of these experiments can be made either through directly comparison of calculated versus measured $\gamma$ or by comparison of calculated $k$-eff with the value of $k$-eff derived from measured $\gamma$. Derived values of $k$-eff depend on calculated values of the 'buckling coefficient of reactivity' which were determined from the CITATION code.

\subsubsection{Worth of Individual Fission Products}

These measurements were made in the Tank-type Critical Assembly (TCA) of JAERI. They consist of the substitution of solutions doped with natural $\mathrm{Sm}, \mathrm{Cs}, \mathrm{Gd}, \mathrm{Nd}, \mathrm{Rh}, \mathrm{Eu}, \mathrm{B}$ and $\mathrm{Er}$ 
at the centre of a critical assembly of $2.6 \%$ enriched UO2 rods in light water. The reactivity of the dopant is determined by the change in critical water height as the doped solution is replaced with undoped solution. In the context of Burnup Credit it is the $\mathrm{Sm}, \mathrm{Cs}$ and $\mathrm{Rh}$ measurements that are of most interest. These give direct evidence of the quality of nuclear data for Sm149, Cs133 and Rh103. Some information on Nd145 and Nd 143 is obtained, since the natural abundances are somewhat similar to the proportions found in spent fuel.

\subsection{Published Information}

The descriptions above are taken from papers at the ICNC'95 [11,12] and PHYSOR'99 [13] conferences. Further papers have been presented at ICNC'99, including detail of sub-critical measurements on spent BWR fuel [14]. Summaries of the sub-critical measurements have also been made at the OECD-NEA Working Group on Burnup Credit.

It would appear that much of the information needed to perform analysis of these experiments is given in the papers. The main area where more information would be needed to establish a benchmark is in the area of uncertainty analysis. Based on information received from one of the authors of both papers, it would appear that more information might be made available following an 'unclassification procedure'.

Comparisons with MCNP for the sub-critical experiments show good agreement, within $1.5 \% \Delta \mathrm{k}$-eff, for both elements, although experimental/interpretative uncertainties are not quoted. Deterministic reactivity perturbation analysis based on JENDL-3.2 gave good agreement for the $\mathrm{Sm}, \mathrm{Cs}, \mathrm{Gd}, \mathrm{Nd}$, and $\mathrm{Eu}$ measurements. Rhodium showed an overprediction in absorption by up to $15 \%$. Total experimental uncertainty is not published, but $5 \%$ uncertainty on the poison concentration is quoted.

\subsection{Observations}

Potentially the sub-critical measurements are of great interest. They provide a direct means of validating Monte-Carlo codes against relatively high burnup fuel. The main drawback is in quantifying uncertainties associated with the measurement and interpretation of the measured parameter. As with all sub-critical measurements some interpretation of the measured parameter, usually via calculation, is needed before the benchmark can be defined in terms of k-eff. This problem is one of the main issues being studied by the recently formed OECD-NEA Working Group on sub-critical experiments. The JAERI experiment would be a welcome addition to the group's program.

One important feature of these experiments is that they have been made for full-length assemblies so that the measurements contain information on the 'end-effect', where the top and bottom end of the fuel has lower burnup than the centre.

The value of the fission product experiments is slightly less clear. In particular, it would be important to understand how representative the fission product cross-sections measured in solutions are compared with cross-sections in spent fuel rods. 


\section{ARIANE \& REBUS}

\subsection{Background}

These two international programs probably represent the most significant experimental work in the area of BUC being carried out at this time. The projects are led by Begonucleaire and have attracted strong support from a range of organisations in Belgium, Germany, Japan, Netherlands, UK and the USA. The ARIANE program was started in 1995 with the aim of establishing a data set of spent fuel isotopics for the three main commercial fuel types (PWR, $\mathrm{BWR}, \mathrm{MOX}$ ) covering nearly 50 of the most important isotopes (including 31 fission products). REBUS will extend the experimental program to cover reactivity measurements on bundles of PWR, BWR and MOX fuel.

\subsection{Technical Program}

\subsubsection{ARIANE}

The ARIANE program is based on the radiochemical analysis of liquid aliquots of dissolved fuel. Analysis is made for 49 different isotopes through a common program in three different laboratories (SCK.CEN, PSI, TUI). In addition, secondary ion mass spectrometry (SIMS) is used to characterize the radial distribution of selected isotopes across fuel pellets.

The aliquots are sampled from dissolved fuel solutions taken from the following sources:

- MOX PWR fuel from BEZNAU with burnups of $\sim 40$ and $\sim 50 \mathrm{GWd} / \mathrm{tM}$

- $\mathrm{UO}_{2}$ PWR fuel from GOESGEN with burnups of $\sim 35$ and $\sim 55 \mathrm{GWd} / \mathrm{tM}$.

- UO2 and MOX BWR fuel from DODEWAARD with burnups of $\sim 35$ and $\sim 55 \mathrm{GWd} / \mathrm{tM}$.

The following isotopic concentrations are determined:

U234, U235, U236, U238, Pu238, Pu239, Pu240, Pu241, Pu242, Np237, Am241, Am242, Am243, Cm242, Cm243, Cm244, Cm245

I129, Cs133, Cs134, Cs135, Cs137, Tc99, Ce144, Nd142, Nd143, Nd145, Nd146, Nd148, Nd150, Sm147, Sm149, Sm150, Sm151, Sm152, Eu153, Eu154, Eu155, Sr90, Mo95, Ru101, Ru106, Rh103, Ag109, Sb125, Pm147, Gd155.

A detailed power history and macrocell description of the core environment is provided for each fuel sample.

\subsubsection{REBUS}

The REBUS program is based on reactivity measurements on bundles of fresh and irradiated fuel pins in a zero power critical facility (LRO:NRI). The bundles are comprised of $\sim 1.2 \mathrm{~m}$ length pins arranged on a square pitch. They are designed to control in the region of $1-2 \%$ $\Delta \mathrm{k}$ relative to fresh fuel. The proposed program includes measurements on three irradiated fuel bundles: 
- PWR UO2 from the BR3 test reactor with burnup of $\sim 30 \mathrm{GWd} / \mathrm{t}$

- PWR MOX from the BR3 test reactor with burnup of $\sim 20 \mathrm{GWd} / \mathrm{t}$

- PWR UO2 from the median section of a commercial PWR with burnup of $\sim 50-60 \mathrm{GWd} / \mathrm{t}$

For the fuel irradiated in the BR3 reactor the bundle length is the same as the height of the core so that the subsequent reactivity measurement in LRO includes the end-effect. In the case of the commercial PWR fuel the burnup in the test bundle is representative of that found at the axial centre of the core and there is no contribution from end-effects to the reactivity measurement.

In addition to the reactivity measurement, destructive radiochemical analysis of the irradiated fuel will be made to provide isotopic concentrations for uranium, plutonium, higher actinides and 18 of the 'TOP' fission products, i.e. Mo95, Tc99, Ru101, Rh103, Pd105, Pd108, Ag109, Cs133, Cs135, Nd143, Nd145, Sm147, Sm149, Sm150, Sm151, Sm152, Eu153, Gd155. Additional Nd isotopics will be measured to provide a burnup indicator. Detail irradiation histories for each bundle will also be provided.

\subsection{Published Information}

At this time published information for both programs is limited to summaries of the experimental programs [15]. Results of the ARIANE measurements are expected to become available in the public domain three years after completion of the program, i.e. $\sim 2002$. The REBUS experiments are expected to start in September 1999 with completion of the measurements and analysis sometime in 2002.

\subsection{Observations}

One of the main features of both these programs is the analysis of fission product inventory in spent fuel. There are very limited data for the most important fission product absorbers and these programs will extend both the enrichment range, the fuel type and the number of fission products analyzed. One of the conclusions of the CERES program is that the most significant uncertainty in fission product contribution to BUC arises from uncertainty in the inventory predictions, so this new data have direct application. It is also recognized that radiochemical analysis is a very complex and delicate process for many of the fission products, so the inclusion of independent measurements from different laboratories in ARIANE is a strong feature. It will be very interesting to see how reproducible the fission product analyzes are.

A potential drawback for the analysis of some of the REBUS fuel bundle reactivity measurements is the irradiation environment in BR3. The core has high heterogeneity with a wide range of experimental fuel rods and with a complex arrangement of fuel elements. This leads to significantly different depletion modeling analysis methods than from burnup calculations for commercial power plant. The addition of a commercial PWR UO2 sample ( $4 \mathrm{w} / \mathrm{o}$ initial enrichment, $\sim 50-60 \mathrm{GWd} / \mathrm{t}$ ) is therefore an important enhancement to the program. As for the Japanese experiments, the use of fuel bundles controlling significant amounts of reactivity, should permit analysis by direct Monte-Carlo methods. This allows 
a more direct validation of the code options commonly used in criticality safety analyzes (i.e. $\mathrm{k}$-eff, rather than reactivity perturbation calculations).

The use of full-core-height bundles irradiated in the BR3 should provide interesting information on the end-effect. It should be noted however that the effect from short fuel from a test reactor may not be closely representative of the effect for longer elements from commercial nuclear power plant.

\section{OTHER POSSIBLE SOURCES OF VALIDATION}

\subsection{Power Reactor Data}

In addition to the dedicated BUC validation experiments reviewed above, further validation of calculated reactivity loss with burnup might also be derived from data obtained from nuclear power plant or other power reactors. For commercial power plant this data is available in the form of critical state points at various stages of the power cycle. In PWR plant the key measured parameter at a state point is the critical soluble boron concentration.

In principle, since this parameter depends on the reactivity worth of fuel burnup, the data could be used to validate calculation methods for BUC. There are however some problems associated with the interpretation of code accuracy for these calculations in terms of uncertainties in calculations for SNF outside the reactor. In particular core reactivity is significantly affected by the presence of any fresh/low burnup assemblies. Also, some key neutronics parameters in the core (e.g. spectrum, axial leakage) may not be very representative of conditions for spent fuel operations. Due to the complexity of the problem, it may also be difficult to establish a well defined benchmark problem amenable to analysis by criticality code methods.

For these reasons it is concluded that while this type of data gives general confidence in the accuracy of modern codes and nuclear data, it may prove difficult to use the information to make quantitative deductions of criticality code bias and uncertainty.

A further possible source of data is from power research reactors or other HEU fueled reactor systems. This may be of particular use in establishing the global reactivity worth of fission products. For HEU fuel reactivity loss with burnup is dominated by U235 depletion and fission product build up, with only small contributions from higher actinide build up. In this situation U235 depletion is a rather simple calculation so that fission product worth might be accurately determined. A further useful feature of these types of core is that reactivity swing during a fuel cycle is often very large. An initial search by the authors of this review has established that useful data may well exist but that some work would be needed to establish precise benchmarks.

\subsection{LWR-PROTEUS Reactor Physics Experiments on High Burnup Fuel}

This program is led by the Paul Scherrer Institute (PSI) and funded mainly by the Swiss utilities. Additional support has been obtained for certain phases from specific partners. The 
Phase 1 experiments were made to investigate power distributions and reactivity effects in boiling water reactors. The aim of the Phase 2 program, scheduled to start in 2000 , is to provide measurements of reactivity loss for high burnup fuel. While the main emphasis of the program is centred on the validation of in-core fuel management calculations, the results should also be applicable to BUC validation.

The proposed program appears to be very similar to the CERES experiments, in that a series of small, well characterized, spent fuel samples will be oscillated in a zero power critical assembly. The provisional plan [16] is for measurements in various core configurations on 6 to 8 samples with initial enrichment $\leq 4.3 \mathrm{w} / \mathrm{o}$, and burnup in the range $40-80 \mathrm{GWd} / \mathrm{t}$. Detailed irradiation histories and isotopic compositions ( 9 major actinides, 8 minor actinides, 17 fission products) are available for each sample to allow testing of both depletion and reactivity calculations.

As for CERES then, these experiments should provide a test of code and nuclear data for both depletion and reactivity calculations. It should be borne in mind that analysis of this type of reactivity measurement has so far been limited to deterministic methods, based on perturbation analysis relative to a set of well defined calibration samples.

At this stage it is not clear what precise restrictions will be placed on the experimental data. Currently the contracts are under negotiation, and it is anticipated that some restriction will apply.

\subsection{DOE PIE Program [17]}

Under contract with General Electric and Argonne National Laboratory, the DOE Yucca Mountain Site Characterization Office is obtaining measured assay data for PWR and BWR fuel with burnups greater than those readily available in the United States to support a disposal criticality analysis methodology. These data, obtained from high burnup Three Mile Island Unit 1 (TMI-1) and Quad Cities Unit 1 (QC-1) fuel assemblies, will extend the maximum burnup in the existing PWR database to more than $50 \mathrm{Gwd} / \mathrm{t}$ and the BWR database to more than $70 \mathrm{Gwd} / \mathrm{t}$. In addition the TMI-1 and QC-1 data will provide extensive measurements on both the actinides and fission products that are important to burnup credit.

Experimental results for some of the fuel samples have been released in draft form, and some reactor physics data is still being compiled. Final results and analysis are not expected before 2001 .

\section{DISCUSSION OF EXPERIMENTS IN RELATION TO US BUC VALIDATION REQUIREMENTS}

BUC validation requirements in the USA are found on 3 main SNF issues:

- Spent Fuel Pool

- Interim Storage and Transport Casks

- Disposal 
Current NRC validation requirements for Spent Fuel Pool BUC assessments are covered by fresh fuel criticals with an additional allowance of $5 \%$ of the $\Delta \mathrm{k}$ (fresh - burnt) being applied to cover code bias and uncertainty. Other conservatisms are often added in the determination of spent fuel composition. In particular, a high boron concentration is usually assumed in depletion calculations to harden the neutron spectrum and increase Pu build-up. The 5\% allowance might be considered as somewhat arbitrary, although licensees may be required to demonstrate that this allowance bounds any under-predictions for in-core reactivity measurements. Notwithstanding that, the allowance would benefit from clearer justification against experimental validation, particularly since full credit for both actinides and fission products is permitted.

The current position regarding Interim Storage and Transport is summarized in a recent Interim Staff Guidance (ISG-8, Revision 1, July 30, 1999). Several areas of potential concern relative to modeling issues and the completeness of validation are listed. In particular the applicability of the benchmarks used to validate isotopic compositions is highlighted, along with the current lack of critical experiments that are prototypic of spent fuel in a cask. In the context of modeling assumptions, the need to consider spatial variations in burnup (e.g. axial profiles, control rod insertion effects) is identified. Uncertainties and potential nonconservatism in treating extreme/unusual cases are addressed by comparison with the fission product margin.

A risk based criticality safety methodology covering post closure analyzes for the Yucca Mountain repository is presented in a TR [18] submitted to the NRC this year. Validation of depletion calculations is based on essentially the same set of radiochemical assay data as presented in the TR for interim storage and transport, so the comments on applicability (particularly the range of initial enrichment and burnup) will apply. Validation of k-effective calculations is based on 45 commercial reactor criticals (CRCs). These provide an integral validation of the net effect of all isotopes in spent fuel. For intact fuel scenarios (i.e. during early post closure) the criticality and validation issues are similar to the interim storage situations, except that credit is also sought for 15 fission products. For degraded fuel scenarios associated with long term repository behavior, the validation issue might be considered to be of less significance, since the criticality safety analysis will be dominated by uncertainties in the degradation modeling.

Overall it might be concluded that the most significant addition to the validation set would be the acquisition of PIE data for higher initial enrichment, higher burnup and covering a wider set of fission products than is currently available. This could in principle extend the range of applicability of the validation to include $>4 \mathrm{w} / \mathrm{o}$ and $>40 \mathrm{GWd} / \mathrm{t}$ fuel, where the benefits of BUC are greatest. A summary of the current sources of PIE data for PWR, BWR and MOX fuel is presented in Figures 3 -5. It is seen that for all three fuel types, the inclusion of ARIANE and the French PIE data, in particular, would significantly extend the current dataset.

The inclusion of fission product inventory validation would strengthen justification of the current methodology for BUC in spent fuel pools, where explicit credit is already taken for this source of reactivity loss. This is also true for the intact Yucca mountain fuel cases. Based on the results of benchmarking the JEF2.2 nuclear data library against European experiments, 
the uncertainty in the fission product reactivity worth is dominated by uncertainties in isotopic inventory rather than in the fission product absorption cross-sections.

Currently the best sources of spent fuel isotopics data appear to be from the French PIE, ARIANE and REBUS programs. The French program includes samples with $4.5 \mathrm{w} / \mathrm{o}$ initial enrichment and $62 \mathrm{GWd} / \mathrm{t}$ burnup. REBUS will include PIE on a sample of $4 \mathrm{w} / \mathrm{o}-60 \mathrm{GWd} / \mathrm{t}$ PWR fuel, while the ARIANE results will include analysis of a $4.9 \mathrm{w} / \mathrm{o}-54 \mathrm{GWd} / \mathrm{t}$ sample. One point worth re-emphasizing here is the difficulty of obtaining accurate radiochemical analysis for fission products. Experience during the CERES program highlighted the difficulties associated with some of the most important fission products (notably Samarium and Rhodium isotopes). For this reason the ARIANE program in particular, with repeat analyzes in independent laboratories, is interesting. Overall it might prove most prudent to seek more than one source of fission product PIE data.

With respect to validation of spent fuel reactivity calculations, the most important requirement appears to be for experiments which will test the accuracy of codes for a range of conditions. While it is recognized that there is little if any experimental validation for a prototypic cask condition, experiments have been made to establish code performance over a range of neutron spectra. This is a particular feature of the CERES experiments, which included measurements in prototypic PWR spectrum as well as thermalized and strongly epithermal spectra. The series also included measurements in an assembly where there was strong thermal absorption (in hydrogen) competing with absorption in the spent fuel. A similar approach is being considered in the LWR-PROTEUS Phase II program, where modifications to spectrum in the test zone may be made through selection of suitable moderator and absorber materials. At this stage however, no firm proposals detailing modified test zones are available.

A further area of possible interest arises from the lack of an integral experimental BUC reactivity benchmark amenable to direct analysis by standard Monte Carlo criticality methods. (The CERES and LWR-PROTEUS experiments are essentially reactivity perturbation experiments requiring deterministic analysis). In principle it would be useful to establish a reference experiment, benchmarked by Monte Carlo codes, then use the other types of experiment to infer code bias and uncertainty over a range of problems. In this category the REBUS fuel substitution measurement offers the simplest source of benchmark data. Other possibilities include the use of CRCs or the Japanese sub-critical measurements on spent PWR and BWR assemblies. In these cases however there would need to be significant studies made to assess the applicability (particularly the CRCs) and correct interpretation (particularly the sub-critical measurements) of the experiments.

The REBUS program also promises to provide information on end-effects associated with the axial burnup profile. This will be interesting information, but it should be borne in mind that the measurement will not be for a prototypic commercial fuel. At this time the dominant uncertainty associated with axial burnup profile is probably not related to code accuracy but more to do with identifying the range of profiles shapes that should be considered. In this context, it is probably gamma scanning measurements associated with the French PIE program that offers the best source of data. 


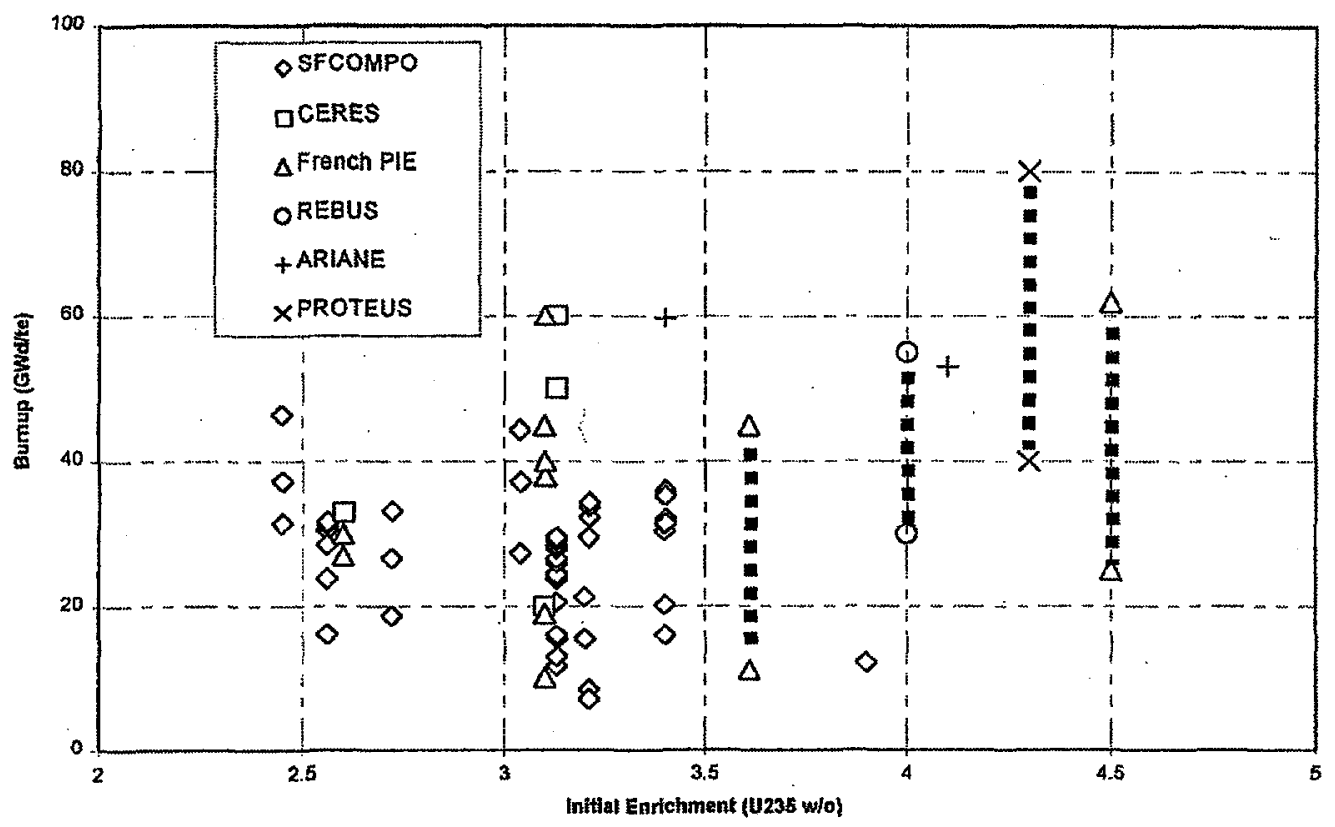

However, licensees usually verify that the bias and uncertainty bound the predicted minus measured reactivity at various measured core conditions, which lends confidence to the reactivity and nuclide concentrations generated for the spent fuel pool criticality analyses.

Figure 3. Summary of PIE Data for PWR UO2 Fuel.

Notes to Figure 3:

1) All the points shown have minimum of $\mathrm{U}+\mathrm{Pu}+\mathrm{Nd}$ isotopics.

2) The French programme includes Minor Actinides (Am, Np, Cm) plus supplementary measurements to determine global FP reactivity.

3) CERES covers the same isotopes as the French PIE programme (for the Phase I PWR Samples) and global FP measurements. Isotopics for 13 of the top fission products are available for a Calvert Cliffs PWR sample $(3 \mathrm{w} / \mathrm{o}, 44 \mathrm{GWd} / \mathrm{te})$. These account for about $75 \%$ of total fission product absorption.

4) ARIANE includes the above isotopics data for actinides \& $\mathrm{Nd}$ plus isotopics for 23 fission products. REBUS isotopics will cover the same actinides $+\mathrm{Nd}+18$ fission products. The fission products in ARIANE and REBUS account for between $80-90 \%$ of the total fission product absorption cross-section.

5) Points joined by dotted lines indicate a set of samples of varying burnup 


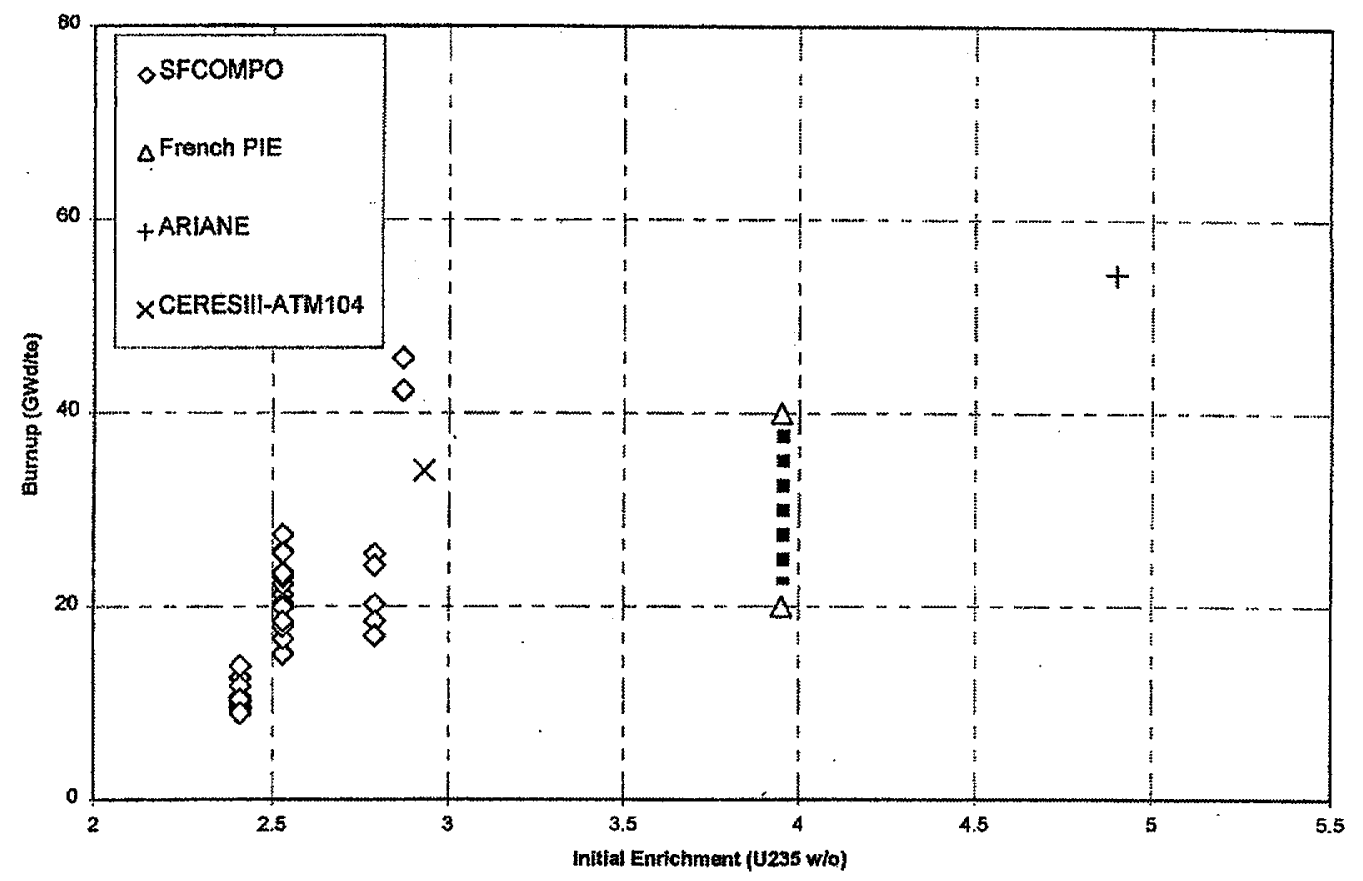

Figure 4. Summary of PIE Data for BWR UO2 Fuel.

Notes to Figure 4:

1) All the points shown have minimum of $\mathrm{U}+\mathrm{Pu}+\mathrm{Nd}$ isotopics.

2) The French programme includes Minor Actinides ( $\mathrm{Am}, \mathrm{Np}, \mathrm{Cm}$ ) plus supplementary measurements to determine global FP reactivity.

3) The CERES-ATM104 BWR sample covers the same isotopes as the French PIE programme and spent fuel reactivity measurements. Isotopics for 13 of the top fission products are also available. These account for about $75 \%$ of total fission product absorption.

4) ARIANE includes the above isotopics data for actinides plus isotopics for 23 fission products. These fission products account for $80-90 \%$ of the total fission product absorption cross-section.

5) Points joined by dotted lines indicate a set of samples of varying Burnup. 


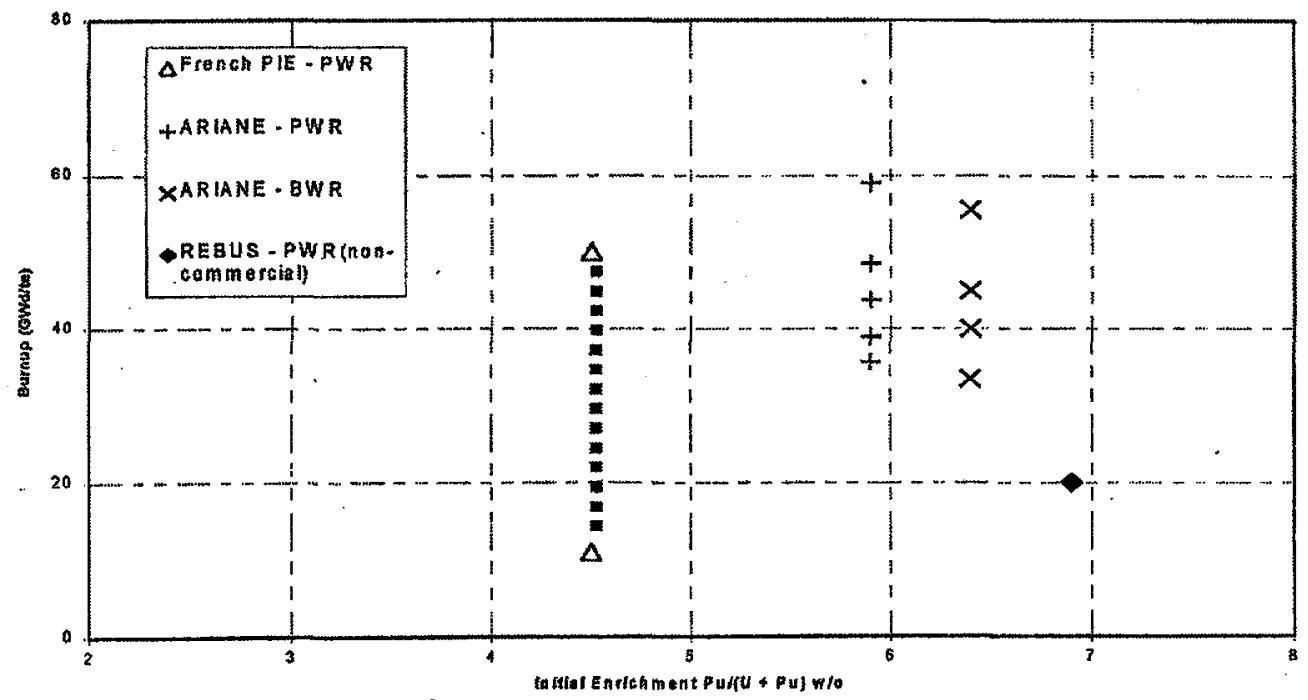

Figure 5. Summary of PIE Data for MOX Fuel.

Notes to Figure 5:

1) All the points shown have minimum of $U+P u+N d$ isotopics.

2) The French programme includes Minor Actinides ( $\mathrm{Am}, \mathrm{Np}, \mathrm{Cm}$ ) plus supplementary irradiated sample reactivity measurements.

3) ARIANE includes the above isotopics data for actinides plus isotopics for 23 fission products. These fission products account for $80-90 \%$ of the total fission product absorption cross-section.

4) The REBUS isotopics analyses cover minor actinides plus 13 fission products. This fuel has been irradiated in the BR3 research reactor.

5) Points joined by dotted lines indicate a set of samples of varying burnup 
10.

\section{CONCLUSIONS}

An extensive review of international experimental programs has been carried out. The key BUC validation data arising from those programs are summarised in Sections $2-8$ of this report. The experiments, carried out in Europe and Japan include both PIE data giving spent fuel isotopic composition, and direct measurements of spent fuel reactivity.

Comparing the experiments with current US validation requirements for existing and anticipated BUC methodologies, it is concluded that the most significant benefits would be realized by the acquisition of certain PIE data. In particular, the ARIANE and French PIE programs offer important extensions to the existing US validation set, and will bring key information on higher initial enrichment, higher burnup and on fission product inventory in spent fuel. This will benefit validation of spent fuel pool, interim storage \& transport and disposal methodologies. The GEDEON experiments would provide valuable data for Gadolinium loaded fuel.

The REBUS program also includes PIE data for higher burnup fuel and for fission products. REBUS also offers the opportunity of establishing an integral spent fuel reactivity benchmark to test standard Monte Carlo methods. This will provide a unique reference point for criticality codes. Extension of the validation to applications away from the REBUS reactivity benchmark could be made through analysis of certain types of 'reactor physics' measurements. These include the CERES and LWR-PROTEUS programs. A further source of data in this category arises from commercial reactor critical (CRC) data, but the applicability of these measurements to out-of-core operations would need to be assessed. The HTC experiments provide a solid basis for actinide only burnup credit.

Overall we conclude that, on a technical basis, the priority for adding more data to the current validation set is as follows:

1. French \& ARIANE PIE programs

2. REBUS PIE and Spent Fuel Reactivity Measurements

3. CERES (and perhaps LWR-PROTEUS Phase II, when completed), and HTC

4. Other sources, e.g. CRCs (with applicability analysis), research reactor data (reactivity loss with burnup). 


\section{REFERENCES}

1. C. Chabert et al., "Experimental Validation of UOX and MOX Spent Fuel Isotopic Predictions," Volume 2, Proc. PHYSOR'96, September 1996, Mito, Japan.

2. A. Santamarina et al., "The French Experimental Program on Burnup Credit," Proc. Topical Meeting of the Nuclear Criticality Safety Division, September 1997, Chelan, WA.

3. P. Chaucheprat et al., "Qualification of the UO2 - Gd2O3 Depletion Calculation Through the GEDEON Experiments," Proc. Topical Meeting on Advances in Reactor Physics, Mathematics and Computation, April 1987, Paris, France.

4. J. Anno et al., "Planned experimental Program Qualifying the Safety Margins Given by 6 Selected FP's in Spent Fuels," Proc. Topical Meeting of the Nuclear Criticality Safety Division, September 1997, Chelan, WA.

5. F. Barbry et al., "French Experimental Criticality Programs. Potential of the IPSN/Valduc Criticality Laboratory," ICNC'95, September 1995, Albuquerque, NM, USA.

6. F. Barbry et al., "Experimental Criticality Study Programmes and Test Potential of the IPSN Valduc Criticality Laboratory," ICNC'99, September 1999, Versailles, France.

7. Y. Chanzy et al, "COGEMA/TRANSNUCLEAIRE's Experience with Burnup Credit," in IAEA TECDOC-1013, Implementation of Burnup Credit in Spent Fuel Management Systems, October 1997, Vienna.

8. J. Gulliford et al., "Experimental Validation of Calculational Methods and Data for Burnup Credit," add-on manuscript, Conference Program, ICNC'95, September 1995, Albuquerque, NM, USA.

9. A. Santamarina et al., "Experimental Validation of Burnup Credit Calculations by Reactivity Worth Measurements in the Minerve Reactor," Volume 1, Conf. Proc. ICNC' 95, September 1995, Albuquerque, NM, USA.

10. J. Gulliford et al., "Measurements of the Reactivity Loss with Burnup in PWR, BWR and MOX Fuel made in the CERES Collaborative Programme," Volume 2, Conf. Proc. PHYSOR 96, September 1996, Mito, Japan.

11. T. Suzaki, "Exponential Experiments of PWR Spent Fuel Assemblies foe Acquiring Subcriticality Benchmarks Usable in Burnup Credit Evaluations," Volume 1, Conf. Proc. ICNC'95, September 1995, Albuquerque, NM, USA

12. M. Kurosawa, "Isotopic Composition of Spent Fuels for Criticality Safety Evaluation and Isotopic Composition Database (SFCOMPO)," Volume 1, Conf. Proc. ICNC 95, September 1995, Albuquerque, NM, USA. 
13. Y. Komuro et al., "Measurements of Reactivity Worths of Natural Sm, Cs, Gd, Nd, Rh, Eu, B and Er," Volume 4, PHYSOR'96, September 1996, Mito, Japan.

14. T. Suzaki et al., "Measurements of Criticality Properties of a BWR Spent Fuel Assembly", Volume 4, Conf. Proc. ICNC'99, September 1999, Versailles, France.

15. J. Basselier et al., "Some Applications of ARIANE and REBUS to Source Term, Criticality and Burnup Credit Issues." INMM Spent-Fuel and High Level WasteManagement Conference, January 1999, Washington D.C. USA.

16. T. Williams, "Phase II of the LWR-PROTEUS Programme," The Experimental Determination of Reactivity Effects of Burnup in LWRs: A Concept Document. PSI, April 1999.

17. I.C. Gould and C.V. Parks, "Interim Information Report: A Review of Experimental Istopic Assay Data for Spent LWR Fuel," ORNL, February 2000.

18. Disposal Criticality Analysis Methodology Topical Report, Rev. November 1998. 


\title{
Internal
}

S.K. Bhattacharyya

P. Finck (10)

E. Fujita (5)

G. Imel

H. Khalil

J. Liaw

T. Taiwo

D. Wade

T. Yule

TIS

\section{External}

\author{
ANL-E Library \\ ANL-W Library \\ DOE/OSTI (2) \\ C. Nilsen (10), Nuclear Regulatory Commission, Rockville, MD \\ Jim Gulliford (5), AEA Technology, United Kingdom
}

